\title{
RECONNAISSANCE REPORT: FLOODING RESULTING FROM TYPHOON URING IN ORMOC CITY, LEYTE PROVINCE, THE PHILIPPINES
}

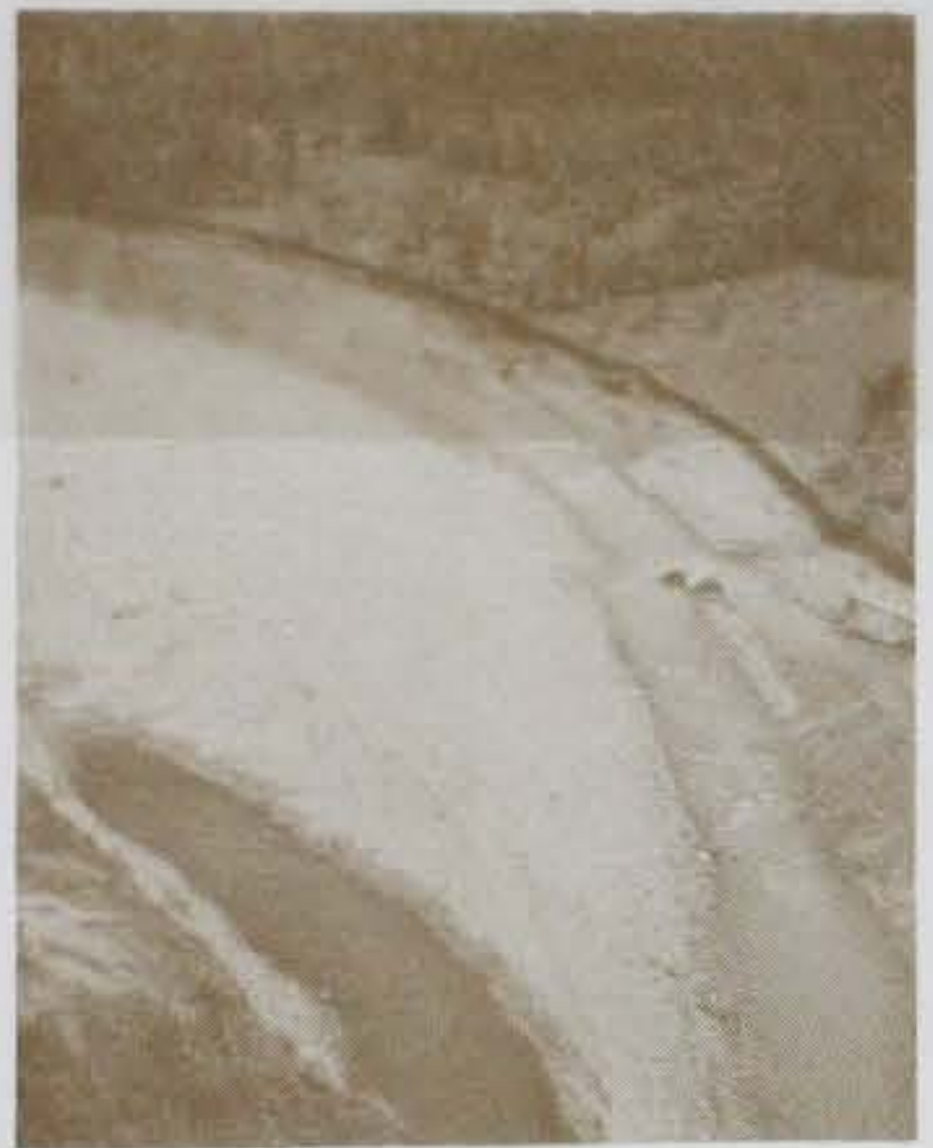

by

Monte L. Pearson

Geotechnical Laboratory

DEPARTMENT OF THE ARMY

Waterways Experiment Station, Corps of Engineers 3909 Halls Ferry Road, Vicksburg, Mississippi 39180-6199

and

John G, Oliver

Hydraulics and Civil Design Branch

DEPARTMENT OF THE ARMY

North Pacific Division, Corps of Engineers

Portland, Oregon 97208-2870

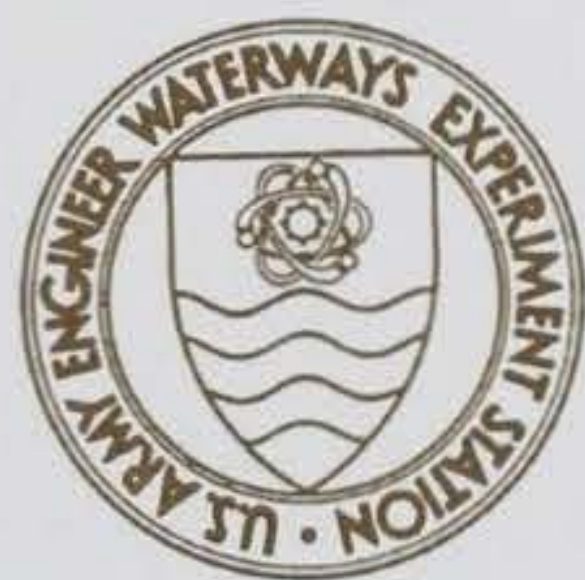

June 1992

Final Report

Approved For Public Release; Distribution Is Unlimited

RESEARCH LIBRARY

US ARMY ENGINEER WATERWAY:

EXPERIMENT STATION

VICKSBURG, MISSISSIPPI

Prepared for DEPARTMENT OF THE ARMY

US Army Corps of Engineers

Washington, DC 20314-1000 


\section{REPORT DOCUMENTATION PAGE}

Public reporting burden for this collection of information is estimated to average 1 hour per response, including the time for reviewing instructions, searching existing data sources. gathering and maintaining the data needed, and completing and reviewing the collection of information. Send comments regarding this burden estimate or any other aspect of this collection of information, including suggestions for reducing this burden. 10 Washington Headquarters Services. Directorate for information Operations and Reports. 1215 Jefferson Davis Highway, Suite 1204. Arlington, VA 22202-4302, and to the Ottice of Management and Budget, Paperwork Reduction Project (0704-0 188), Washington, DC 20503.

\begin{tabular}{|c|c|c|}
\hline 1. AGENCY USE ONLY (Leave blank) & $\begin{array}{c}\text { 2. REPORT DATE } \\
\text { June } 1992\end{array}$ & $\begin{array}{c}\text { 3. REPORT TYPE AND DATES COVERED } \\
\text { Final report }\end{array}$ \\
\hline
\end{tabular}

4. TITLE AND SUBTITLE

Reconnaissance Report: Flooding Resulting from
Typhoon Uring in Ormoc City, Leyte Province, The Philippines

\section{AUTHOR(S)}

Monte L. Pearson, John G. Oliver

7. PERFORMING ORGANIZATION NAME(S) AND ADDRESS(ES)

See reverse.

\section{PERFORMING ORGANIZATION} REPORT NUMBER

Misce11aneous Paper GL-92-12

\section{SPONSORING/MONITORING AGENCY NAME(S) AND ADDRESS(ES)}

US Army Corps of Engineers

Washington, DC 20314-1000

\section{SPONSORING/MONITORING} AGENCY REPORT NUMBER

\section{SUPPLEMENTARY NOTES}

Available from National Technical Information Service, 5285 Port Royal Road, Springfield, VA 22161.

\begin{tabular}{|l|l}
\hline 12a. DISTRIBUTION/AVAILABILITY STATEMENT & 12b. DISTRIBUTION CODE
\end{tabular}

Approved for public release; distribution is unlimited.

\section{ABSTRACT (Maximum 200 words)}

Typhoon Uring passed over the Island of Leyte on 5 November 1991 on an east to west track north of Tacloban City and Ormoc City. The center of the typhoon was at the midpoint of the Island about 10:00 a.m. and took 3 to $4 \mathrm{hr}$ to pass across the Island width. Widespread damage from flooding was left in its wake. The Coastal Plain from Ormoc City at the north to Baybay at the south situated at the western side of the Island received major damages. The Ormoc watershed and Ormoc City were the hardest hit areas.

\begin{tabular}{|c|c|c|c|}
\hline \multirow{2}{*}{$\begin{array}{l}\text { 4. SUBJECT TERMS } \\
\text { Flood } \\
\text { Island of Leyte }\end{array}$} & \multirow[b]{2}{*}{$\begin{array}{l}\text { Ormoc City } \\
\text { Tacloban City }\end{array}$} & \multirow[b]{2}{*}{ Uring } & \multirow{2}{*}{$\begin{array}{l}\text { 15. NUMBER OF PAGES } \\
62 \\
\text { 16. PRICE COOE }\end{array}$} \\
\hline & & & \\
\hline $\begin{array}{l}\text { 17. SECURITY CLASSIFICATION } \\
\text { OF REPORT } \\
\text { Unclassified }\end{array}$ & $\begin{array}{l}\text { 18. SECURITY CLASSIFICATION } \\
\text { OF THIS PAGE } \\
\text { Unclassified }\end{array}$ & $\begin{array}{l}\text { 19. SECURITY CLASSIFICATION } \\
\text { OF ABSTRACT } \\
\text { UnClassified }\end{array}$ & 20. LIMITATION OF ABSTRACT \\
\hline
\end{tabular}


7. (Concluded).

USAE Waterways Experiment Station Geotechnical Laboratory 3909 Halls Ferry Road

Vicksburg, MS 39180-6199

North Pacific Division, Corps of Engineers Hydraulics and Civil Design Branch

Portland, Oregon 97208-2870 
PREFACE

This work described in this report was authorized by Headquarters, US Army Corps of Engineers (HQUSACE) under agreement with US Department of State, Office of US Agency for International Development (USAID), based on a request for assistance from the Philippine Government Development of Public Works and Highways.

This report was prepared by Dr. Monte L. Pearson of Geotechnical Laboratory (GL), US Army Engineer Waterways Experiment Station (WES) and Mr. John G. Oliver, Chief, Hydraulics and Civil Design Branch, North Pacific Division.

Site guidance and logistical assistance were provided by Messrs. John Starnes, USAID/Philippines and Pacifico G. Mendoza, Jr., Regional Director, Department of Public Works and Highways, Government of the Philippines, and staff member.

The work was conducted under the general supervision of Dr. William F. Marcuson, Director, GL; MAJ General Harrel Ernest, Jr., Commander, Messrs. Robert Flanagan, Chief, Planning and Engineering, and Edward Daugherty, Chief, Technical Engineering Branch.

At the time of publication of this report, Director of WES was Dr. Robert W. Whalin. Commander and Deputy Director was COL Leonard G. Hasse11, EN. 
Typhoon Uring passed over the Island of Leyte on 5 November 1991 on an east to west track north of Tacloban City and Ormoc City. The center of the typhoon was at the midpoint of the Island about 10:00 a.m. and took 3 to 4 hours to pass across the Island width. Widespread damage from flooding was left in its wake. The Coastal Plain from Ormoc City at the north to Baybay at the south situated at the western side of the Island received major damages. The Ormoc watershed and Ormoc City were the hardest hit areas.

The storm speed and the accompanying intense rainfall were the main causes of the damages. Because of the storm's speed on the eastern slope of the mountain range, low elevation runoff passed through the Coastal Plain before higher elevation runoff was routed to the coastline. Conversely, on the westside the higher elevation runoff arrived at the coast about the same time that lower elevation runoff was most intense.

Rainfall intensities were extremely high with $140.2 \mathrm{~mm}$ recorded at Tacloban City in 3 hours, $580.5 \mathrm{~mm}$ and $350.0 \mathrm{~mm}$ recorded in 36 hours at PNOC Raingage 1 and 2. The major portion of the rain at PNOC is reported to have occurred in 3 hours. Extremely intense rainfall was also reported to have occurred at Ormoc City in a 3-hour period.

Soils in the region were totally saturated a short time after inception of intense precipitation. Soil strengths were decreased and significant surface failure occurred to a depth of about 1 to $3 \mathrm{~m}$ in the upper basin. Stream bank and bed erosion was also intense. Bulking of flows by sediments contributed to the magnitude of the flood. It is also likely that the upper river basins both east and west experienced debris flows that at lower elevation dropped to intense sediment transport leaving the larger boulders but continuing to carry woody debris and up to gravel size material that was capable of damming bridge sections.

Streams in the region are well incised, and side slopes have limited stability. Evidence of high sediment transport prevail throughout the systems. Stream lower reaches are braided at low flow and have numerous channels. Stream bed slopes are high, estimated to exceed 1 percent within $200 \mathrm{~m}$ of their mouths and average 5 to 7 percent throughout their lengths on the western slopes. Under those circumstances, stream orientation under various 
flows is difficult to predict. Deep erosion around hardened surfaces, bank protection, bridge piers, abutments, and contractions are normal. Large fluctuations in river bed elevations are common as sediment pulses pass through reaches.

The intense flood at Ormoc City which lies just below the confluence of the Antilao River and Malbasag River was caused by extremely intense rainfall and upper basin soil instability. The major loss of life at Ormoc City occurred just upstream of the main City, in the Isla Verde area. Flood plain zoning may have assisted in reducing the losses experienced.

Factors that could reduce future localized flooding and infrastructure damage are improved approach alignments of the streams with bridges, reduction of stream contraction, and raising of bridge decks to prevent damming of bridge section with debris. Based on the 5 November 1991 flood event and a future risk analysis, bridge redesign criteria development throughout the system should give consideration to river alignment, existing river widths and the latent instabilities associated with high velocity major sediment and debris transporting systems.

The following is a list of recommendations.

1. Provide zoning to prevent habitation in high risk areas.

2. Provide flood warning systems where practicable.

3. Establish the frequency and size of the event so both risk and the economic impact of remedial measures can be analyzed.

4. Improve design criteria for infrastructure.

5. Stabilize slide surfaces to minimize sediment mobilization during minor events.

6. Provide stream improvement and diversions. 
CONTENTS

$\underline{\text { Page }}$

Preface . . . . . . . . . . . . . . . . . . . . . . . . i

Executive Summary . . . . . . . . . . . . . . . . . . . . . . . . . . . 1

Background . . . . . . . . . . . . . . . . . . . . . . . . 6

Mission . . . . . . . . . . . . . . . . . . . . . . . 6

Geologic Setting . . . . . . . . . . . . . . . . . . . . 7

Drainage System . . . . . . . . . . . . . . . . . . . . . . . . . . . 8

Channel Morphology . . . . . . . . . . . . . . . . . . . . . . . . . 9

Ormoc City and Delta Area . . . . . . . . . . . . . . . . . . . . . . . 11

Meteorological Conditions . . . . . . . . . . . . . . . . . . . . 12

The Flood . . . . . . . . . . . . . . . . . . . . . . . . . . . . . . . 13

Bridge Damage . . . . . . . . . . . . . . . . . . . . . 15

Conclusions . . . . . . . . . . . . . . . . . . . . . . . . . . 16

Recommendations . . . . . . . . . . . . . . . . . . . . . . . 17

Bibliography . . . . . . . . . . . . . . . . . . . . . . . . . 19

Appendix A: List of Contacts . . . . . . . . . . . . . . . . . . . . . A1

Appendix B: Rainfall Data NPOC . . . . . . . . . . . . . . . . . . . B1 
No.

1 Antilao River Channel Profile and Cross-Section Stationing . . . . 20

2 Cross Section 1 Antilao River . . . . . . . . . . . . . . . . . . 21

3 Cross Section 2 Antilao River . . . . . . . . . . . . . . . . . . 22

4 Cross Section 3 Antilao River . . . . . . . . . . . . . . . . . . 23

5 Cross Section 4 Antilao River . . . . . . . . . . . . . . . . . . 24

6 Cross Section 5 Antilao River . . . . . . . . . . . . . . . . . 25

7 Cross Section 6 Antilao River . . . . . . . . . . . . . . . . . . 26

8 Malbasag River Channel Profile and Cross-Section Stationing . . . 27

9 Cross Section 1 Malbasag River. . . . . . . . . . . . . . . . . . 28

10 Cross Section 2 Malbasag River . . . . . . . . . . . . . . . . . . 29

11 Cross Section 3 Malbasag River . . . . . . . . . . . . . . . . . . 30

12 Cross Section 4 Malbasag River . . . . . . . . . . . . . . . . . . 31

13 Cross Section 5 Malbasag River . . . . . . . . . . . . . . . . . 32

14 Antilao River Stage Hydrography at Ormoc City . . . . . . . . . . 33

15 Flood Routing . . . . . . . . . . . . . . . . . . . . . . . . . . 34 
1 Upper Drainage Area Ormoc Watershed . . . . . . . . . . . . . . . 36

2 Middle Basin Channel Ormoc Watershed . . . . . . . . . . . . . . . 37

3 Lower Basin Channel Ormoc Watershed . . . . . . . . . . . . . . . 38

4 Failed Bridge and Woody Debris Deposition Area . . . . . . . . . . 39

5 Antilao River Above Ormoc City . . . . . . . . . . . . . . . . . . 40

6 Isla Verde Area and Antilao River Bridge . . . . . . . . . . . . . 41

7 Tree Blowdown Ormoc Watershed . . . . . . . . . . . . . . . . . 42

8 Bridge Failures . . . . . . . . . . . . . . . . . . . . 43

No.

1 Location Map . . . . . . . . . . . . . . . . . . . . . . . . . . . 44

2 Ormoc City Area Map, Two Rivers and Flooded Areas . . . . . . . . 45

3 Ormoc Watershed . . . . . . . . . . . . . . . . . . . . . . . . . 46

4 Storm Track for Typhoon URING . . . . . . . . . . . . . . . . . . 47

5 Sediment Routing Basin Map . . . . . . . . . . . . . . . . . . . . 48

6 Ormoc City to Baybay Leyte Coastal Highway No. 302 . . . . . . . . 49 
RECONNAISSANCE REPORT: FLOODING RESULTING FROM TYPHOON URING

IN ORMOC CITY, LEYTE PROVINCE, THE PHILIPPINES

\section{Background}

The Philippines is an archipelago of 7,107 islands and stretches from the south of China to the northern tip of Borneo. Total population is about 60 million. Leyte is one of the major islands and lies at about $11^{\circ} 15^{\prime} \mathrm{N}$ latitude (Map 1).

Leyte Province is located on the Island of Leyte in the Republic of the Philippines. The island is $350+\mathrm{km}$ south southeast of the capitol city of Manila. Typhoon Uring moved onto the island early Tuesday morning on 5 November. Although storm winds were relatively weak, packing sustained winds of only $55 \mathrm{kph}$, it unleashed heavy rains over Leyte beginning on 4 November on a Monday night. The rains became extremely intense Tuesday morning. Landslides in the mountains were triggered and vast parts of lower elevation areas of western slopes were flooded by mud and water by noon Tuesday.

The flooding is considered to be the worst to have occurred in the Philippines in 7 years. Up to $3 \mathrm{~m}$ of soil laden floodwater submerged Ormoc City and outlying towns. Coastal area residents were caught without warning. The death toll was extensive with most being drowned or buried in mud as their houses were swept away. The city of 0rmoc with a population of 150,000 was hardest hit with approximately 4,800 dead and 1,857 missing.

Bridges along the western coastline received severe damage. In total, 16 bridges were damaged or destroyed. Most of this occurred between the cities of Ormoc and Baybay. Early estimates of property damage have been P 395M. Agricultural crops, poultry, and livestock accounted for P 35M, infrastructure, P $130 \mathrm{M}$ and private properties, and public facilities accounting for the remaining $\mathrm{P}$ 230M. Power failure was widespread as power poles were destroyed.

\section{Mission}

On 12 November 1991, Headquarters, US Army Corps of Engineers was contacted by the Department of State regarding Corps assistance on determining the cause of the flooding and possible mitigation measures. Two engineers 
with extensive experience in river morphology were dispatched to the Philippines on 4 December 1991. The team was comprised of Mr. John G. Oliver, Chief, the Hydraulics and Civil Design Branch, North Pacific Division, and Dr. Monte L. Pearson, Senior Research Scientist, Geotechnical Laboratory, US Army Engineer Waterways Experiment Station.

The team spent 5 December through 13 December 1991 in the country. Meetings were held with the US Agency for International Development, and primarily with the Philippine Government Department of Public Works and Highways . The basic requesting letter, complete listing of contacts, and basic trip itinerary are included in Appendix A.

\section{Geologic Setting}

The Island of Leyte was formed by volcanic action consisting of strata volcanoes, dome complexes, pyroclastic/tephra cones calderas and compound volcanoes (Philvocs Annual Report 1988). The volcanic core complex is concentrated on the north central portion of the island. The central areas are classified as "volcanic terrain."

The Philippine Fault System is the major tectonic feature of the region. The system trends NW-SE through Leyte with all of the volcanic cones resting on the eastern block of the Philippine Fault. The intense tectonic activity has highly sheared and fractured all geologic formations on Leyte.

The basement geology of Leyte is pretertiary igneous and metamorphic rocks traversing the length (North-South Axis) of Leyte. Fluvial marine and terrace gravel deposits of early Neogne-Latte Preleogene overlay the basement complex. Pleo-Pleistocene volcanic formation of andesitic composition is the youngest exposed formation within the area. The flanks of the volcanic complex are blanketed by pyroclastic materials mainly of Lahar origin. The Lahar deposits in the watershed area are typical poorly sorted (boulder-pebblegravel sized andesitic clusts) and matrix (sand size). The lowlands are fluvial sediments of unconsolidated matrix gravel type.

The soils in the Ormoc watershed have been classified by the Philippine Bureau of Soils as "upland soils." They are characterized by undefined soil horizon with great erosion potential. Soils are formed originally from decomposed andesitic rocks. These are granular and noncohesive, unstable and 
highly susceptible to erosion and transport. The upper watershed has steep slopes, and a high rate of soil formation due to rapid decay of andesitic rock materials and climatic factors. In order to maintain slope equilibrium an equal volume of soil mass removal and reformation occur (regolith). The numerous fresh slide in Bao, Malitbog, and the other drainage included in the Ormoc watershed support this data. High rainfall rates serve as a catalyst which triggers the majority of the shallow mass movements. The Department of Science and Technology (Department of Science and Technology 1991) also supports this finding, and it states that the average soil profile is $7 \mathrm{~m}$ thick.

\section{Drainage System}

The Regional Disaster Coordinating Council of Region 8 (Regional Disaster Coordinating Council 1991) provides a complete description of the Ormoc watershed. Ormoc watershed is composed of three major subdrainage basins. This report will only describe the northwestern two drainage. They are the two major systems directly associated with the 5 November 1991 flooding of Ormoc City.

The Antilao and Malbasag Rivers are the two major drainage systems that directly impacted Ormoc City. These two rivers converge upstream of Ormoc City and the Isla Verde Area (Map 2).

The Antilao River drains the northernmost portion of the watershed and is composed of three subbasins (Map 3). The middle portion of the watershed is drained by the Malbasag River and only has one subbasin. The Malbasag River is the smallest of the two in area and channel length, $10.8 \mathrm{~km}$ compared to $16.3 \mathrm{~km}$ for the Antilao drainage (Figures 1 and 2). The total drainage length of the two systems is approximately $27.0 \mathrm{~km}$.

Drainage in the Ormoc watershed is dendritic in pattern and well incised. Upper channel incisions are characterized by a 1/3-width/depth ratio based on a ridge/stream measuring system. Progressing downstream the width/ depth ratio just upstream of Ormoc City is about 3 to 1 .

The Antilao River has a vertical drop of $84.5 \mathrm{~m}$ in $13.2 \mathrm{~km}$ on the mainstem for an average of 6.4 percent slope, whereas, the Malbasag River has a slope of 6.2 percent. The average fall of both streams is $64.8 \mathrm{~m} / \mathrm{km}$. All the streams in the Ormoc watershed flow southwest and converge above or near 
Ormoc City (Map 2). The confluence of the two rivers is $2.5 \mathrm{~km}$ from the Camotes Sea. The junction is about $5 \mathrm{~m}$ above average sea level (ASL). The mainstem is 13 to $15 \mathrm{~km}$ in length and drains approximately $190 \mathrm{~km}^{2}$.

Data gathered during field reconnaissance indicate that mass movements were shallow failures ranging from 1 to $3 \mathrm{~m}$ in depth (Photos 1 and 2) and 50 to 100 wide at head failure zone. Movement generally occurred from ridge line to the channel bottom. The soil mass in the upper watershed has been classified as cohesionless media which failed at a ratio of length/depth to shear plane of 10 to 100 . Photos 1 and 2 provide positive illustration of this relation.

In a dry state these cohesionless soils rely upon interparticle frictional strength for stability. Upon wetting, the interparticle frictional strength is reduced, and as total saturation occurs, the strength factor is reduced to 0 at which time failure occurs. Further, the highly weathered and relatively thick soil masses have developed internal shear planes. Subjected to intense rainfall, the shear planes become failure planes. The short and high intensity rainfall in these circumstances created mass movement features that were long and shallow. Combining all the data, surface soil mass with internal shear planes, stream side slopes exceeding 60 percent, and cohesionless soil, it is apparent that during wet conditions the slopes in the upper $2 / 3$ of the Ormoc watershed are highly unstable.

\section{Channel Morphology}

For descriptive purposes the Ormoc drainage basin has been divided into three basic valleyway-channel geometries (upper, middle, and lower) that are directly related to the geomorphology of the region (both slope and channel processes).

The upper basin area represents the areas of highest topographic relief drainage and are the headwaters for the basins. Down-drainage out of channel topography has slopes up to 30 percent. Side slope in the valleyway channels are up to 60 percent. According to Land Resource Evaluation Report (LRER) Leyte Province (Bureau of Soils and Water Management 1986), this area constitutes 20 percent of the watershed area. Channelways are deeply incised with near vertical channel walls up to $10 \mathrm{~m}$ above the channel bed (Figures 2-3 
and 9-10). Large historical mass movement scars are visible with recent (5 Nov 91) small failure scar superimposed. The dates of historic failures are unknown, but dating could be used to aid in establishing flow frequencies.

The width/depth ratio normally related to change geometry has been modified to represent channelway and channel area. The channelway is the deeply incised area with the active channel (braided) in the basin area. The upper basin area width/depth ratio is nearly 1 to 3 . This portion of the watershed has experienced the highest percentage of mass movement events. The majority and most recent are shallow failure features which normally ran out to the channel area at the base of the slope. Material delivered by this process is saturated. Upon delivery to the stream, materials are immediately entrained and the total flow is bulked by the added sediment. Flow bulking by sediments was a significant phenomena during the 5 November 1991 storm in the higher and steep channel slope areas. The sediment-laden water was transported down the deep, narrow and generally straight channel system to the Middle Basin Area (Photo 3).

The Middle Basin Area terrain has slopes of 18 to 30 percent and represent about 18 percent of the total basin (Bureau of Soils and Water Management 1986). The width/depth ratio changes to approximately 2 to 3 and the channel side slopes are still steep at 60 percent (Figures 4-5 and 11-12). Again, shallow mass movement features are prevalent along the channel valleyway. Sediment loading and bulking processes were similar to that in the upper basin area. With the increase in discharge, bed degradation and bank erosion processes produced additional sediment to the system. The channel in plan view at the low flow is more meandering and braided. At higher flow this meandering and braided form undoubtedly disappears.

The lower basin area (excluding Ormoc City and the Delta Area) is still well incised with a width/depth ratio of about 3 to 2 . Meandering and channel braiding are the major low flow plan form features. Down-drainage slopes are reduced to 8 to 18 percent.

The mainstream of the Antilao and Malbasag Rivers, as stated earlier, are incised and highly meandering in this reach (Figures 6-8 and 12-13). The meanders induce a high degree of channel sinuosity, which create deposition zones upstream of each meander bend (Photo 3). Momentum loss and backwater effect results in deposition of the boulder/gravel material in transport. 
Loss in momentum, produced by the sharp direction change, reduces stream power which reduces transport capacity. Once the flow has exited, the meander stream power is regained, and bend, bed, and bank erosion/scour occurs. This sedimentation/erosion process repeats itself through the lower reach. With each repetition the $D_{50}$ size of material transported is reduced. This process explains the lack of a large volume of boulder to gravel size sediments within the flood effected area of Ormoc City. The gravels and finer fractions did continue down the system and deposited in the city and Camotes Sea. Significant amount of woody debris was also transported and may have formed up as part of a debris flow at the front of the flood (Photo 4).

\section{Ormoc City and Delta Area}

The Ormoc City/Delta Reach can be considered the delta/beach reach of the system. Town development and cultural features have fixed the channel location. The junction of Antilao and Malbasag Rivers just upstream of Ormoc City creates a single major river through town. The channel width/depth ratio through town appears to be 3 to 1 ; however, the incision and width are not natural. The channel geometry has been adjusted and the reach is smaller than those of the lower basin areas. The reduction in flow area and adjustment of slope associated with the delta are contributing factors which resulted in massive out-of-channel flow in the Ormoc City area. Photos 5 and 6 show that

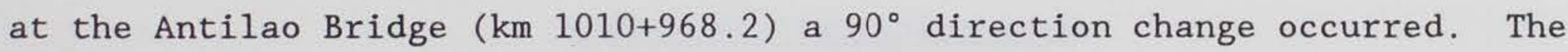
momentum change combined with the contraction should have had the severe effect of putting initial flow overbank at this location. Along with debris flow and woody material impacting this area, the bridge was eventually removed. Flood water entered the Ormoc City street system to a depth of 3 to 5 feet, creating significant property damage. The recent lobate deposit at the mouth of the system suggests that the coarse fraction of sediment continued to transport in the channel and through the town to Ormoc Bay. The Isla Verde area upstream of the Antilao Bridge was flooded several feet above overbank, and residents living within the floodplain were decimated (Photo 6). Ormoc City is located at the lowest elevation on the coastal delta of the Antilao and Malbasag Rivers. Both drainage join about $2.5 \mathrm{~km}$ from the coastline and $1 \mathrm{~km}$ north of Ormoc City Proper. At the confluence point the 
drainage is wide. Significant residential development within riverbank lines and on banklines between Ormoc and the confluence point had occurred prior to the flood.

Highway No. 302 channelizes the drainage system to the northside of the highway. The emplacement of Antilao River Bridge induces a $90^{\circ}$ channel bend. At the bridge site the channel changes from $300 \pm \mathrm{m}$ wide by 3 to $4 \mathrm{~m}$ deep to 30 to $40 \mathrm{~m}$ wide and $10 \mathrm{~m}$ deep. The change continues from the river bridge through Ormoc City to the bay. The constriction greatly increases the flood potential immediately upstream and through the City (Photos 4, 5, and 6, Map 2).

Upstream of the Antilao River Bridge in the Isla Verde area (Map 2 and Photo 5) is a zone composed of a colluvial sediment of gravel and sand size. The material is representative of the deposition area of steep braided gravel channels. As stated earlier, this section of the floodplain was densely inhabited. Based on information provided by the Ormoc City Engineer, there were a variety of dwelling types; none able to withstand a significant flow event.

A third drainage system (Biten River) flows just to the east and south of Ormoc City Proper. The extent of flooding or impact on the Antilao and Malbasag Rivers flooding of Ormoc City was not determined but could have been a factor.

\section{Meteorological Conditions}

Tropical Storm Uring developed on 2 November 1991 and continued until 6 November 1991. Uring was a relatively small and weak storm system. Uring maintained typhoon status for less than 24 hours starting about 1000 hours on 5 November 1991, while located some $350 \mathrm{~km}$ east of the region. The storm tracked east to west across Leyte passing north of the Ormoc City Area. After crossing Leyte, Uring weakened to a tropical depression and on 6 November 1991 at 10:00 am, tropical depression Uring dissipated to a low pressure system (Map 4).

As the storm system advanced on Leyte, intense rainfall started about 0730 hours on 5 November 1991 at Tacloban City (Map 4). Rainfall records at 
the Tacloban Airport indicated $140.2 \mathrm{~mm}$ of rainfall in a 24 -hour period with the most intense occurring in only 3 hours, 0730 to 1030 hours.

Intense rainfall began about 0830 hours at the PNOC rain gages $1+2$ (Map 3). At about 1130 hours the highest rainfall intensity had decreased or stopped according to PNOC officials. Uring was traveling at $12 \mathrm{kph}$ as it moved across the Island. Based on travel speed and distance, intense rainfall should have started in Ormoc City at about 0930 hours on 5 November 1991. As per conversations with city officials, intense rainfall did occur approximately 0930 hours on 5 November 1991. Rainfall intensity and winds were of a high magnitude; areas of extensive blowdown occurred. Photo 7 shows an area of blowdown in the upper drainage section of the watershed.

Rainfall records (Table 1) from November 1976 to 1991 for the VISCA weather station located $8 \mathrm{~km}$ north of Baybay, Leyte provides a general indication of rainfall quantities for the coast areas period of record. Baybay is located $30 \mathrm{~km}$ south from Ormoc City and some $850 \mathrm{~m}$ lower in elevation than the upper portions of the Ormoc watershed. Based on meteorological principles, it is possible to extrapolate that rainfall amounts in the upper watershed areas could commonly be one or two orders higher in magnitude. The VISCA station reported $238.4 \mathrm{~mm}$ in 24 hours compared to PNOC Rain gage No. 2 of $580.3 \mathrm{~mm}$ (the PNOC Hostel and nearest to Ormoc watershed, Map 3). This rain gage is located at an elevation of $435 \mathrm{~m}$ above sea level which is only $2 / 3$ up the drainage basin in relative elevation.

\section{The Flood}

At Ormoc City the flood waters flowed out of the lower basin into the Isle Verde area entraining buildings and most other items in its path. It is probable that a front wall of woody material and debris reached the bridge and restricted flow through the Ormoc City channel. The bridge restricted channel width and $90^{\circ}$ bend created some backwater effect almost instantaneously. Channel width at the available slope was inadequate to contain the flow within banks. The stage hydrograph of the event as described by local residents and partially recorded on video tape is as shown in Figure 14. The water surface rose by 7 feet in 15 minutes, and an hour after flow peaked, the hydrograph was falling. The total flood lasted less than 4 hours. Flow in the streets 
of Ormoc City as recorded on video tape had a depth of 3 to 5 feet. Average sediment depth was described as 2 feet deep after the flood waters had receded. Sediments in the streets were fine grained and characteristic of suspended load. Materials offshore of the river mouth appeared to have a much greater fraction of coarse material, and it is believed that most of coarse material passed through the river channel as near bed suspended load. Sediment transport and flow should then be governed by principles used for Newtonian fluid.

The Special Task Group Regional Disaster Coordinating Council, Region 8 , used the rainfall record of $580 \mathrm{~mm}$ at Tongonan, PNOC Rain gage No. 2 which is nearer and more proximate to the 0 rmoc Watershed and assumed that $80 \mathrm{~mm}$ of the precipitation occurred between $10 \mathrm{p} . \mathrm{m}$. on 4 November to $8 \mathrm{a} . \mathrm{m}$. on 5 November 1991. Based on that assumption, $500 \mathrm{~mm}$ was the rainfall from 8 a.m. to 11 a.m. on 5 November 1991. The total volume of water that flooded Ormoc City was:

$$
\begin{aligned}
& \text { watershed area } \times \text { rainfall } \\
& 4,500 \text { hectares } \times 500 \mathrm{~mm} \text { or } \\
& 45,000 \mathrm{sq} \mathrm{m} \times 0.5 \mathrm{~m} \\
& Q=22,500,000 \mathrm{cu} \mathrm{m} \text { of water }
\end{aligned}
$$

We estimate that about an equal amount of sediment was transported. Assuming a 35 percent porosity in sediments, the total volume of fluid was about $37,000,000 \mathrm{cu} \mathrm{m}$. To estimate the peak flow rate and to get further insight into flood potential at Ormoc City, a preliminary routing was done on the flood. The basin was broken into 6 areas with $500 \mathrm{~mm}$ of rainfall introduced into areas 3, 4, and 5 uniformly between 0800 and 1100 hours on 5 November and in areas 1, 2, and 6 between 0900 and 1200 hours (Map 5). Sediments were introduced in run No. 1 Figure $15 \mathrm{a}$ at 0800 hours and in run No. 2 Figure $15 \mathrm{~b}$ at 0820 hours. Sediment was only introduced in areas 3, 4, and 5 . Sediment introduction was in proportion to rainfall. The flood peak at Ormoc City was at 1050 hours for run No. 1 and at 1120 hours with a 10 -minute shift in initial sediment input on run No. 2. Peak flows were between 70,000 cubic feet per second and 80,000 cubic feet per second, channel capacity through the City is estimated to be much less than 30,000 cubic feet per second. The 
receding side of the hydrograph on both runs is extremely sharp which is the result of the assumptions on where sediment was introduced and upon rainfall intensities.

An inspection of the routings indicates that the slope of the rising leg of the routed hydrograph is too flat, and it is likely that a debris flow was at the front of the actual flood. The debris flow would have retarded the arrival time of the peak because of increased viscosity and friction. It would also have increased the peak flow. The receding side of the hydrography is too steep, based on the local description of the stage hydrograph. Lower elevation sediment entrainment was significant and was not introduced into the simulation, and some ponding occurred in the Isla Verde area. Therefore, a gentler slope would be expected if more realistic assumptions were made.

From the limited analysis, it is evident that the sediment event accompanying the rainfall had a significant influence. Detailed analysis of the hydraulic conditions at Ormoc City could be used to confirm and adjust the routing discharges. The more critical variables could then be reentered into a flood routing program. Variations in the sediment entrainment and routing scenarios could then be used to establish variance in risks associated with different rainfall events.

\section{Bridge Damage}

Bridge damage along Highway 302 between Ormoc City and Baybay was extensive (Map 6). Bridge damages at Ormoc City and in other drainage are the result of over constriction of the stream at bridge crossings and poor alignment. Loss of bridge approach control structures, erosion around piers, deck uplift by debris and loss of abutment fill by piping were the common modes of failure (Photo 8 ). Most of the damaged bridges observed had constricted the river width by 50 percent or more. All bridges appeared to be constructed with near river bed spread footings at piers and gravity section abutments. Approach controls were grouted riprap with little if any toe burial and did not appear to always reach top of bank.

There were numerous cases where the banklines had eroded behind the bridge abutments. It is speculated that bridge constriction created a high differential head across the approach fill. Approach fill fines were piped 
out and a channel developed. Increasing the bridge length would help alleviate the problem under similar flood circumstances.

Other bridges failed because of river bed erosion below pier or abutment toes. Deeper footings, pile supported footings, and longer bridge sections in those cases would be beneficial.

River flow alignments appeared to be a major problem at bridge crossings. The alignment problems were, prior to the flood, partially corrected by grouted revetments.

\section{$\underline{\text { Conclusions }}$}

The combination of topographic, hydrologic and physiographic features on the Island of Leyte leads to rainfall, sediment loading, runoff, and flood problems somewhat unique to steep, short, unstable drainage basins. Western slope drainage basins are more prone to intense runoff than are east slope drainages because of the higher average stream gradient. Flood frequency and net runoff during even modest severe rainfall events are dependent upon the cumulative effects of basin geology, topography, hydrology, and the geomorphic and antecedent moisture characteristics of the drainage basin prior to the event. Rainfall events of similar magnitude may result in very different flooding characteristics depending on event sequencing, antecedent moisture conditions in the basin and residual soil strengths. The flood of 5 November 1991 appears to be a product of event sequencing, rainfall intensity, and soil instability. In the 24 hours prior to the event, the basin had been subjected to significant precipitation. Landslides triggered mud and debris flows during the storm event. Moisture conditions in the drainage were high due to previous rains, and shortly after intense rains associated with typhoon Uring began, soils were totally saturated. Therefore, flow concentration times were short and side slopes were weakened to the point of failure. High precipitation bulking and perhaps the effect of the more viscose mud and water mix on channel roughness culminated in flow depths greatly exceeding channel capacity on the alluvial fan. The peak flow from the event was on the order of two times the flow that would have been expected if major sediment entrainment had not occurred. 


\section{$\underline{\text { Recommendations }}$}

The loss of life at Ormoc is considered the most severe impact of the flooding on Leyte. A significant reduction of this impact can be obtained by preventing habitation in high risk areas. The delta of the Antilao and Malbasag Rivers immediately upstream of Ormoc City Isla Verde Area was densely inhabited prior to the flood. Most of the deaths were among the residents of that particular area. It is now being resettled. Immediate action on zoning to prevent that rehabitation and enforcement of the zoning can go a long way toward mitigating a future disaster.

Another method of reducing loss of life in somewhat lower risk areas than the delta region are flood warning systems. The western slope of Leyte where Ormoc is located is probably not adaptable to this because of the short, steep drainage. Eastern slopes are however well situated for flood warning systems.

Flood control storage systems are measures used elsewhere to control runoff from major events, and have been mentioned in several of the Philippine Government agency reports. Onstream storage does not seem practicable at first assessment. The high sediment yield, steep stream gradients and incised nature of the channels normally make economic development of onstream storage difficult. On the western slopes, offstream storage also appears to be limited by topography. The eastern side may however benefit by offstream storage. Rice paddies and other natural impoundments may already be effective in attenuating major floods.

The frequency of an event is an important factor in determining risk and economic impact. Based on the memory of the population, the most recent flood prior to 5 November 1991 occurred in the 1930 's. Rainfall records observed also indicate that the intensity of the 5 November 1991 event was the greatest in the 19-year period of record. The frequency and the magnitude of this and other events should be determined if economics is to be the basis for costly changes in design criteria for infrastructure or major flood control works. Zoning should also incorporate some logic on risk and risk assessment which depends on flood frequency and magnitude.

Numerous streams flooded during the Uring Typhoon event. Measurement of high flow marks, estimates of sediment yield by quantifying slides mass, and 
hydraulic analysis to establish peak flows combined with flood routings can establish the magnitude of the event. Event frequency may be more elusive as it is believed that it is a function of length of precipitation, intensity of precipitation and the slope stability of the basin at the time of the event. Methods that are used include population interviews, historic landslide analysis, storm frequencies including hindcasts and historic flow measurements. A combination of methods will probably be required in this situation.

Design criteria for infrastructure (i.e. bridges, revetments, power poles, and other items) appear to be based upon fairly modest climatic conditions and upon more tranquil drainage systems. A review of bridge design, river mechanics and international experience may indicate that a change in the design criteria could improve the life-cycle costs of the infrastructures.

The presently active slide areas will continue to yield sediments to the streams at a fairly high rate until naturally revegetated or otherwise stabilized. A storm of lower intensity and water content could produce a higher flow than Typhoon Uring under these circumstances as sediment bulking of the flow could be more pronounced. Steps taken to revegetate and stabilize the slides would reduce the period of risk.

Stream alignment improvements at bridges, hydraulic improvements through populated areas, or diversions around populated areas are possibilities for minimizing impacts. Extensive engineering analysis is required to define the benefits of such options. 


\section{Bibliography}

Bureau of Soils and Water Management. 1986. Land Resources Evaluation Projects, Republic of the Philippines.

Department of Science and Technology. 1991. Scientific Assessment Report: Ormoc City Flood on 5 November 1991, Ormoc Task Force Scientific Study Group, Department of Science and Technology, Republic of the Philippines, 27 November 1991 , p 22.

Ormoc City Engineer. 1991. A Pictorial on Ormoc City Disaster, 5 November 1991, DENR, Region 8, Republic of the Philippines, p 17.

Regional Disaster Coordinating Council, Region 8. 1991. Investigation Report of the Ormoc City Disaster, B/Gen Vicente S. Garcia, Jr., Chairman, Republic of the Philippines, p 66.

Second Leyte Engineering District. 1991. Pictures of Damages caused by Typhoon "Uring" and Flash Flood 2nd LED Ormoc City, 5 November 1991, Republic of the Philippines.

Yolo, Vicente A. Jr., (Submitted by). 1991. Typhoon Damages Reports with Pictures Caused by Typhoon "Uring" Occurred on 5 November, 1991, and Temporary Restoration Work, 3rd Leyte Engineering District Baybay, Leyte Republic of the Philippines. 


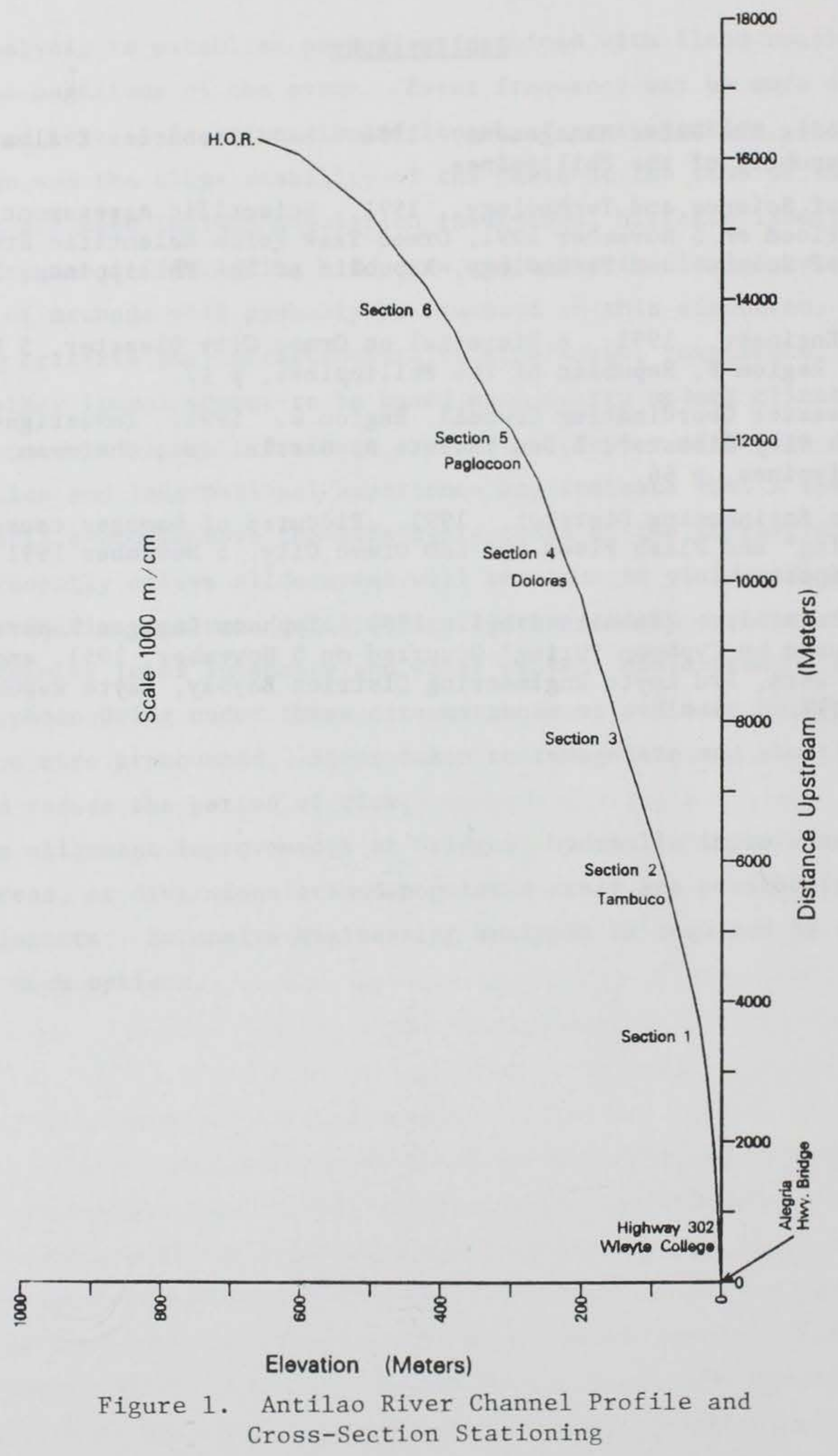




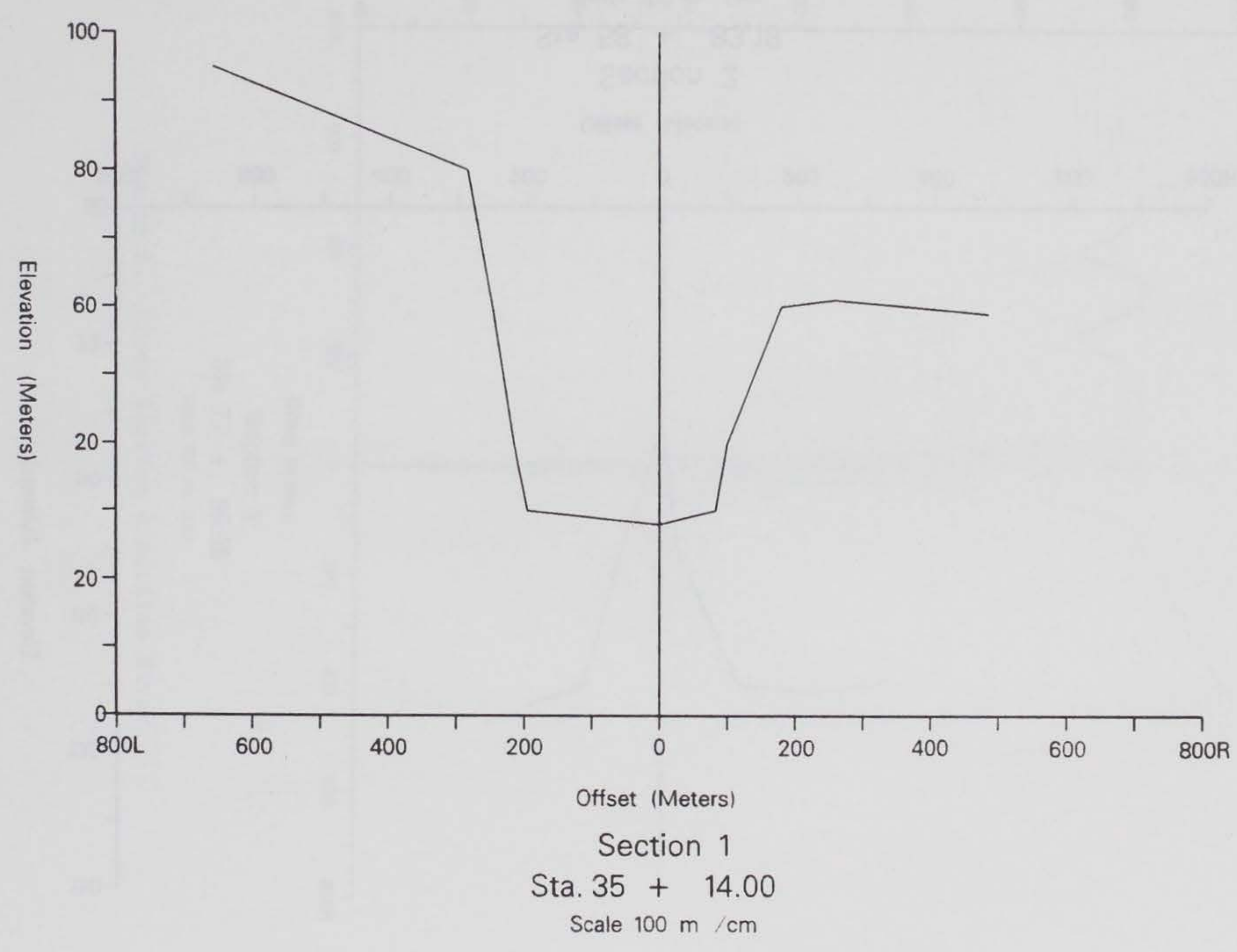

Figure 2. Cross Section 1 Antilao River 


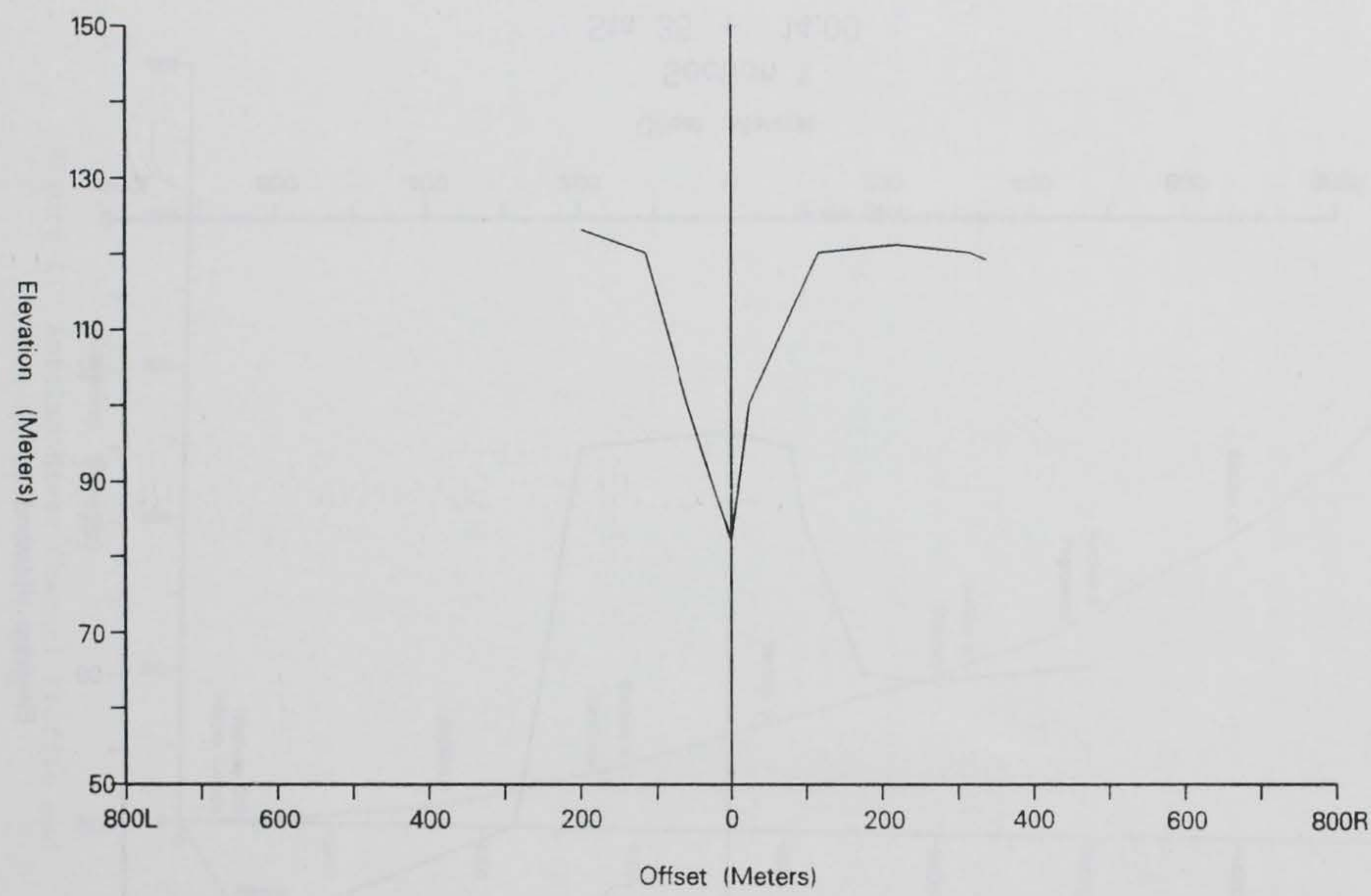

Section 2

Sta. $58+83.18$

Scale $100 \mathrm{~m} / \mathrm{cm}$

Figure 3. Cross Section 2 Antilao River 


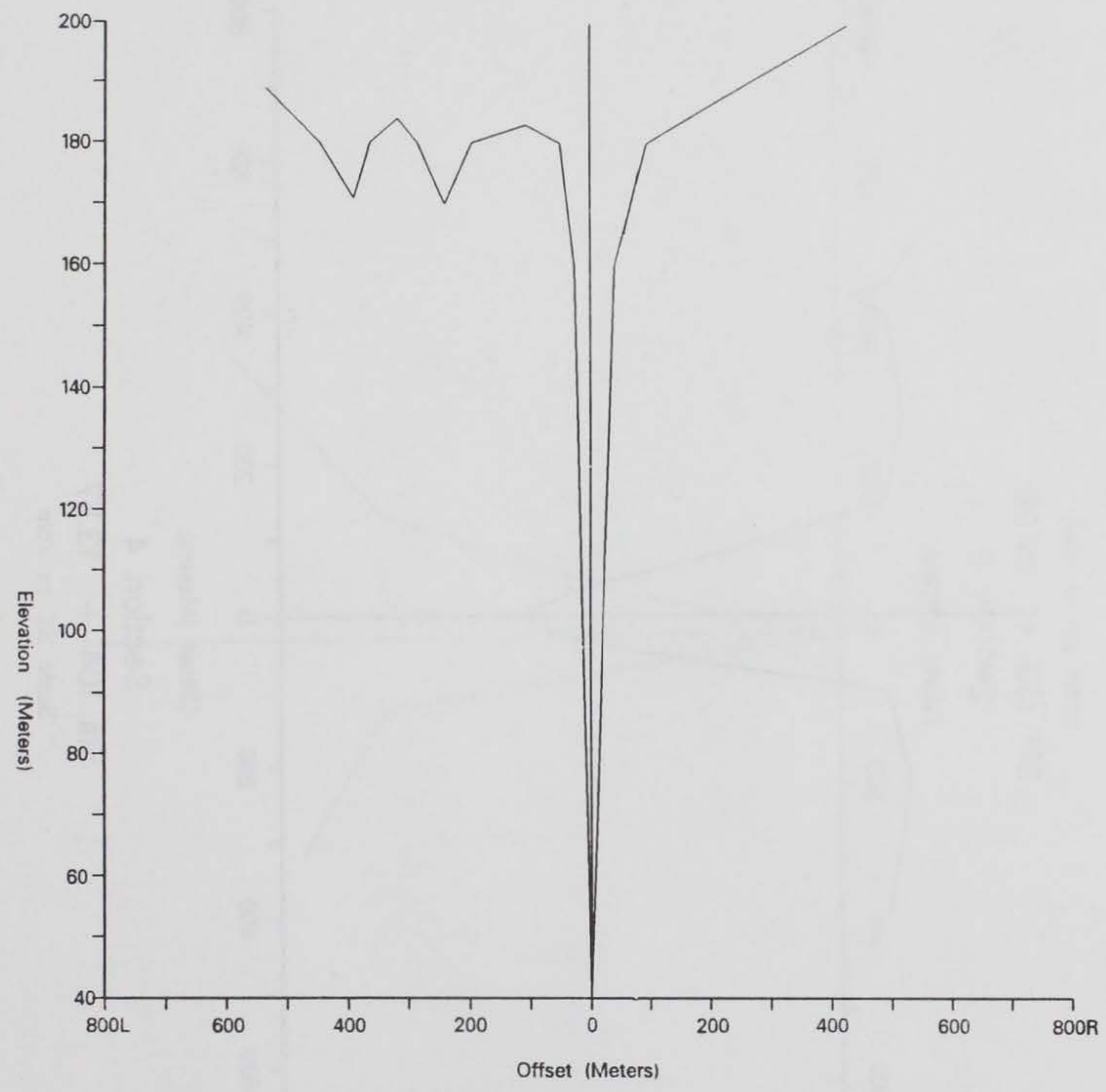

Section 3

Sta. $77+65.08$

Scale $100 \mathrm{~m} / \mathrm{cm}$

Figure 4. Cross Section 3 Antilao River 


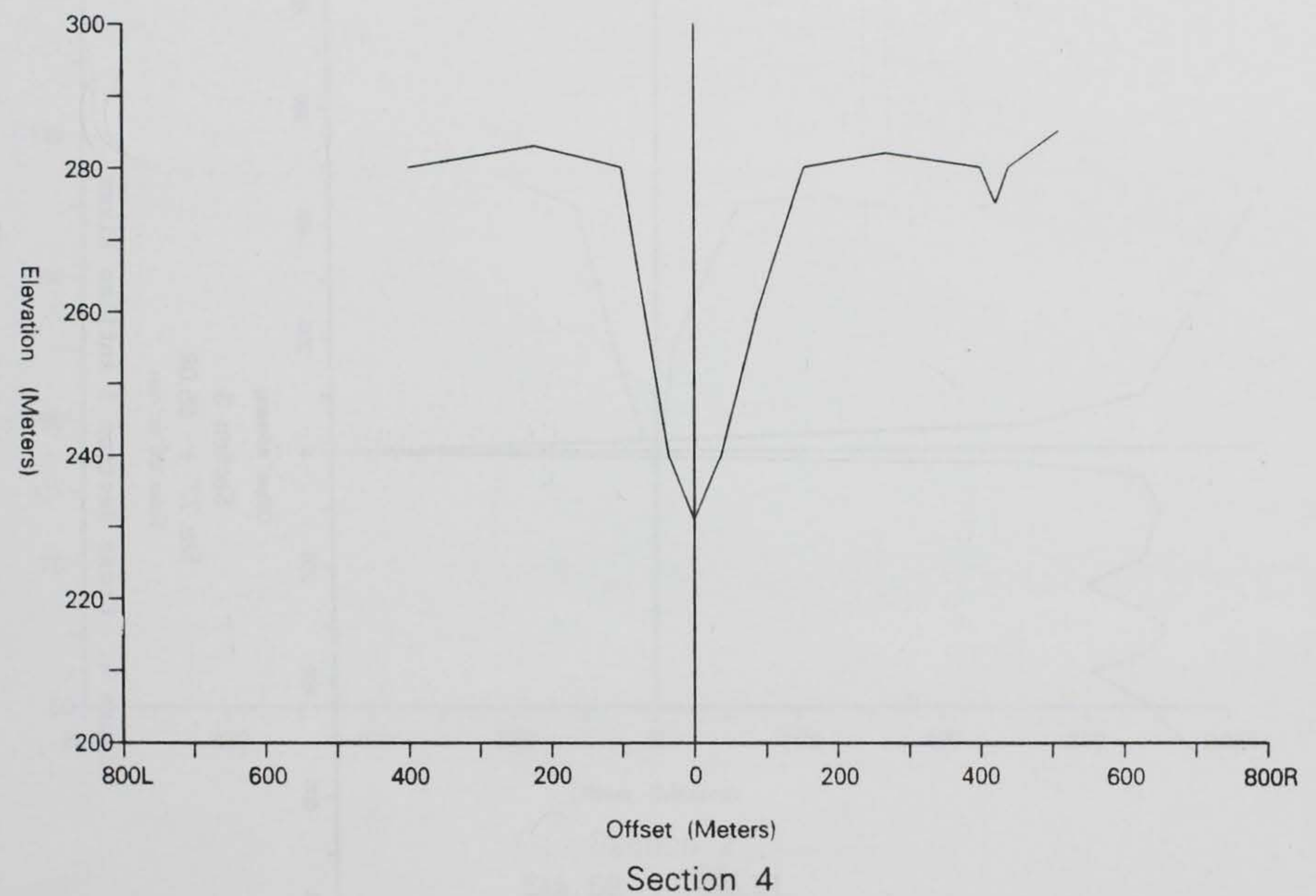

Sta. 104 + 13.57

Scale $10 \mathrm{C} \mathrm{m} / \mathrm{cm}$

Figure 5. Cross Section 4 Antilao River 
$\stackrel{N}{\sim}$

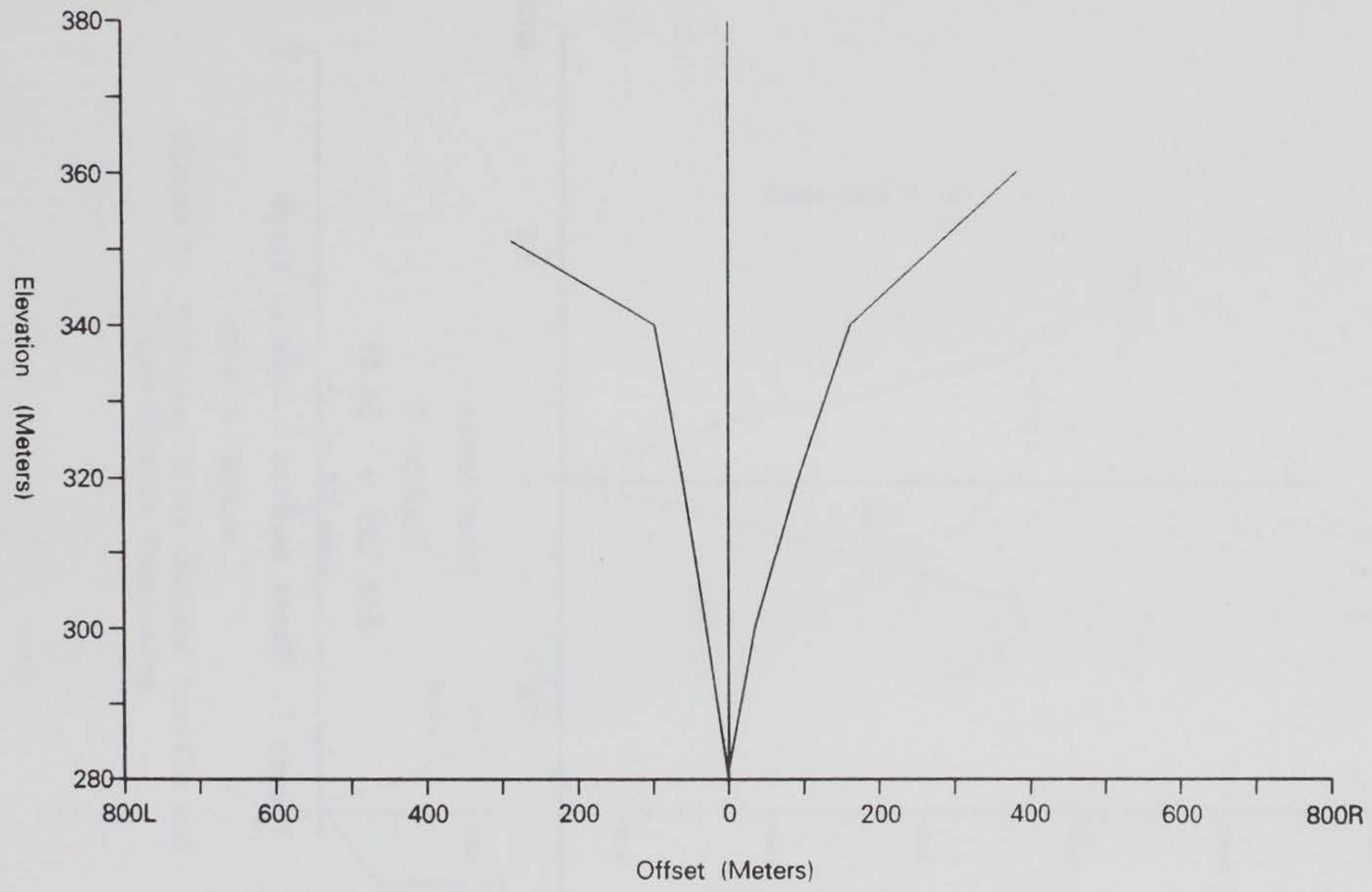

Section 5

Sta. $120+44.06$

Scale $100 \mathrm{~m} / \mathrm{cm}$

Figure 6. Cross Section 5 Antilao River 


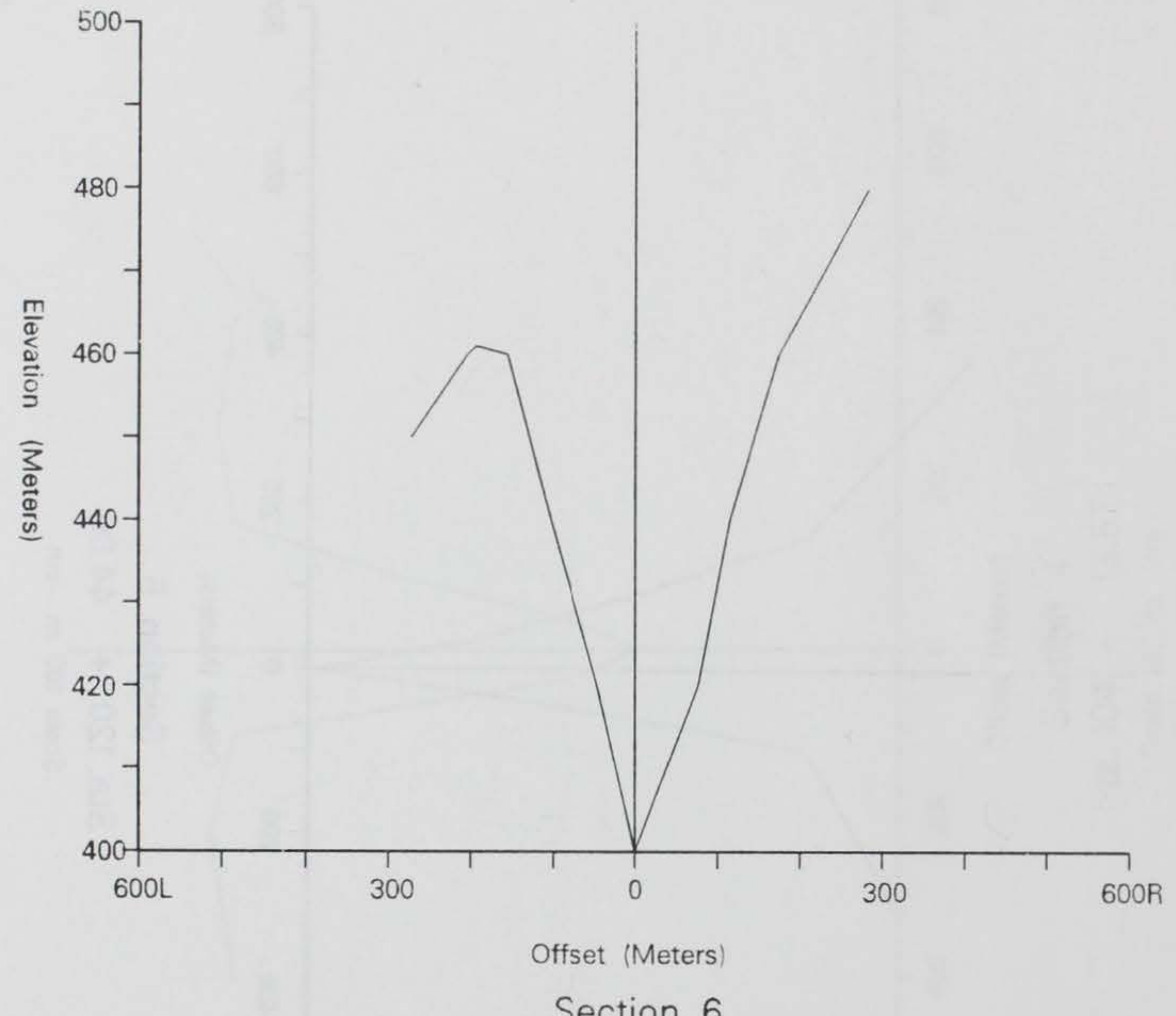

Section 6

Sta. $138+64.41$

Scale $100 \mathrm{~m} / \mathrm{cm}$

Figure 7. Cross Section 6 Antilao River 


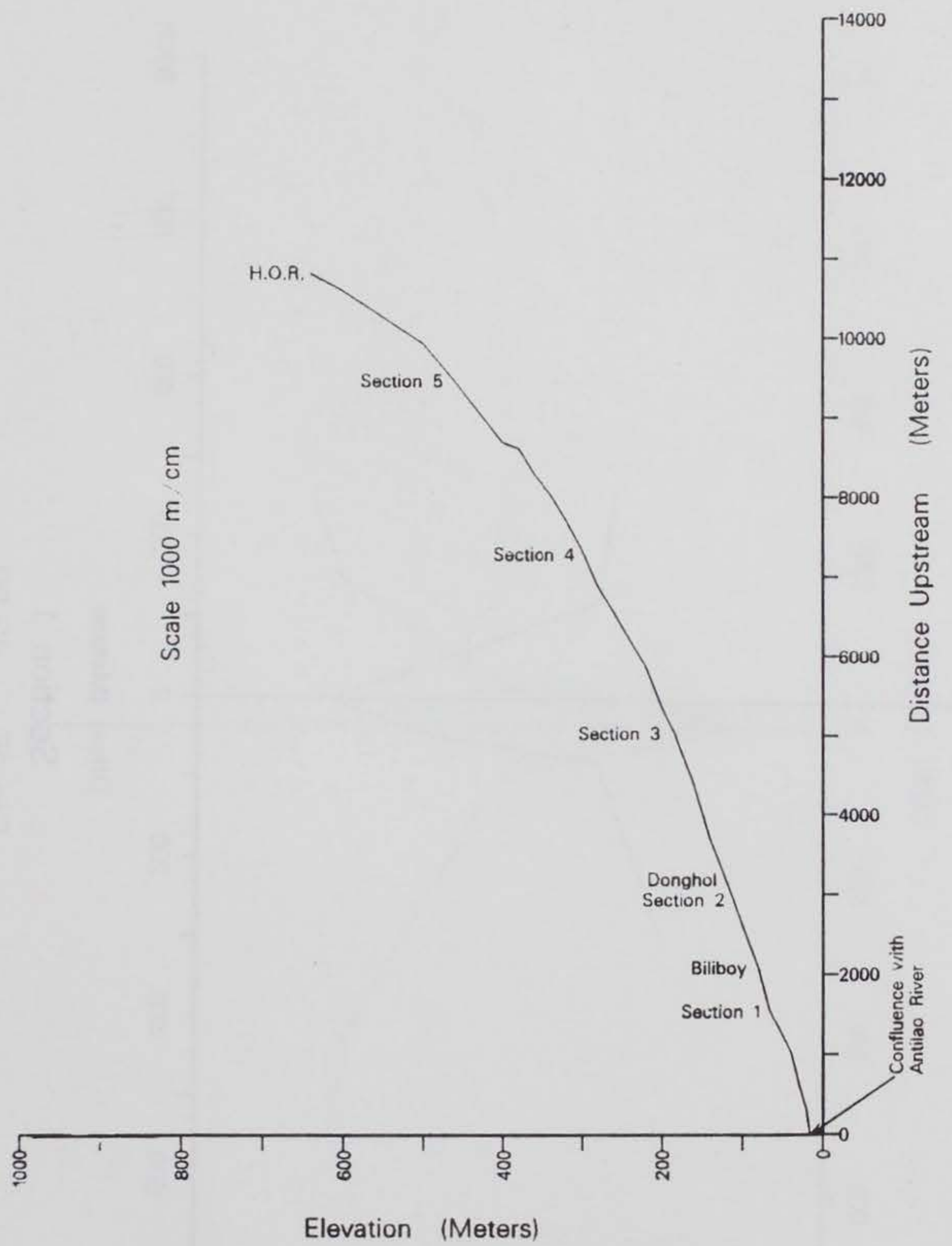

Figure 8. Malbasag River Channel Profile and Cross-Section Stationing 


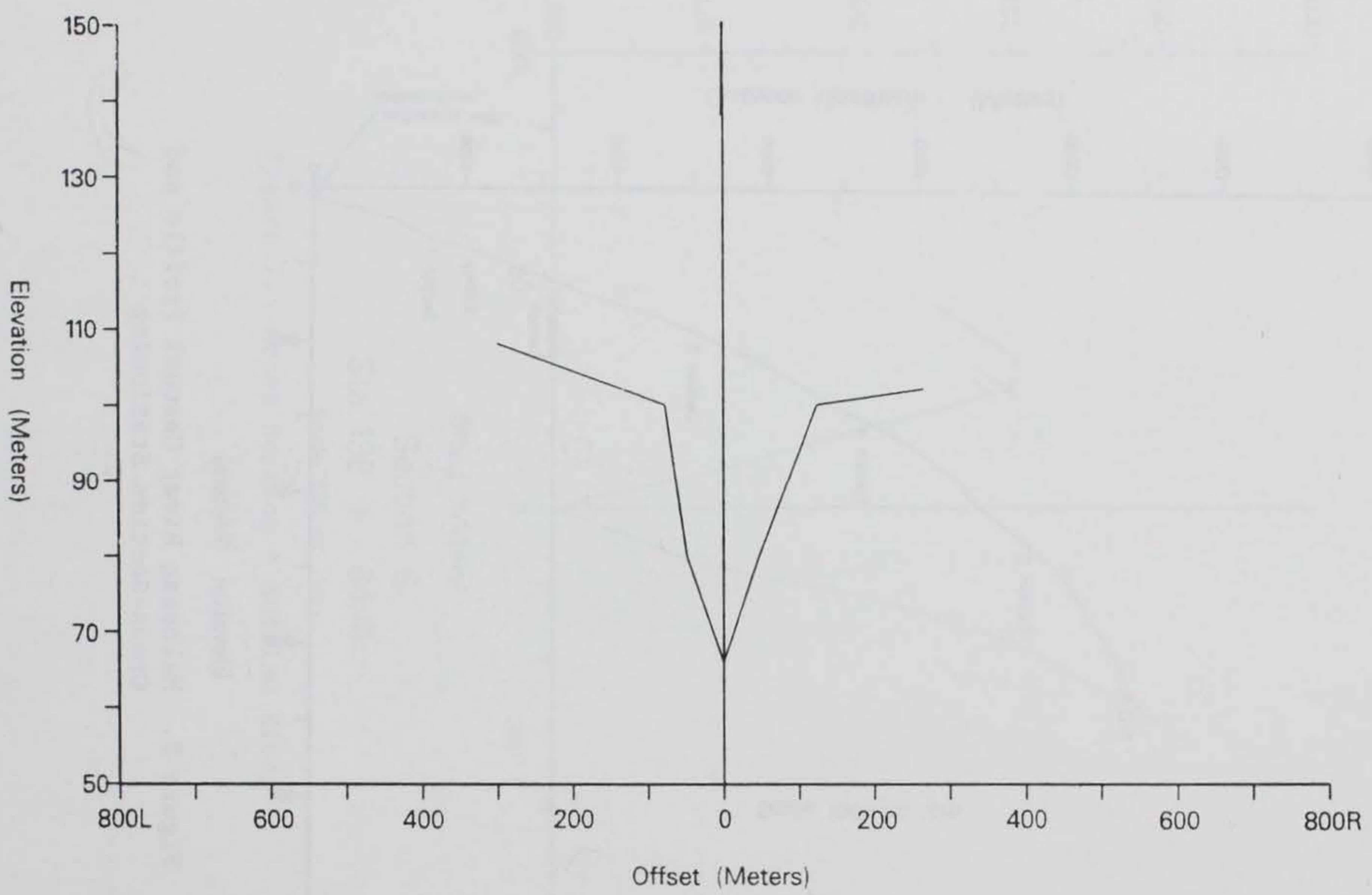

Section 1

Sta. $15+43.00$

Scale $100 \mathrm{~m} / \mathrm{cm}$

Figure 9. Cross Section 1 Malbasag River 


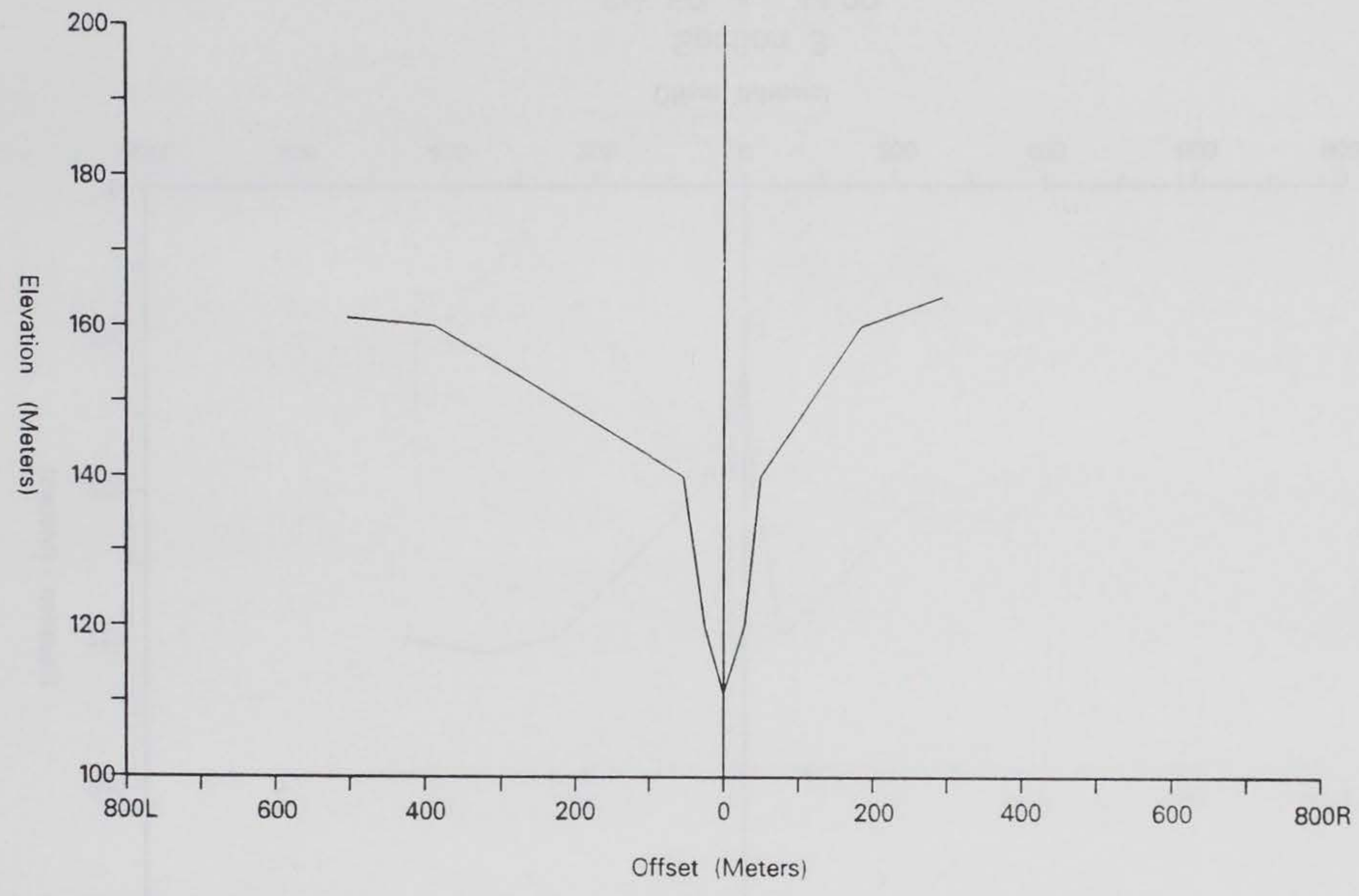

Section 2

Sta. $29+46.00$

Scale $100 \mathrm{~m} / \mathrm{cm}$

Figure 10. Cross Section 2 Malbasag River 


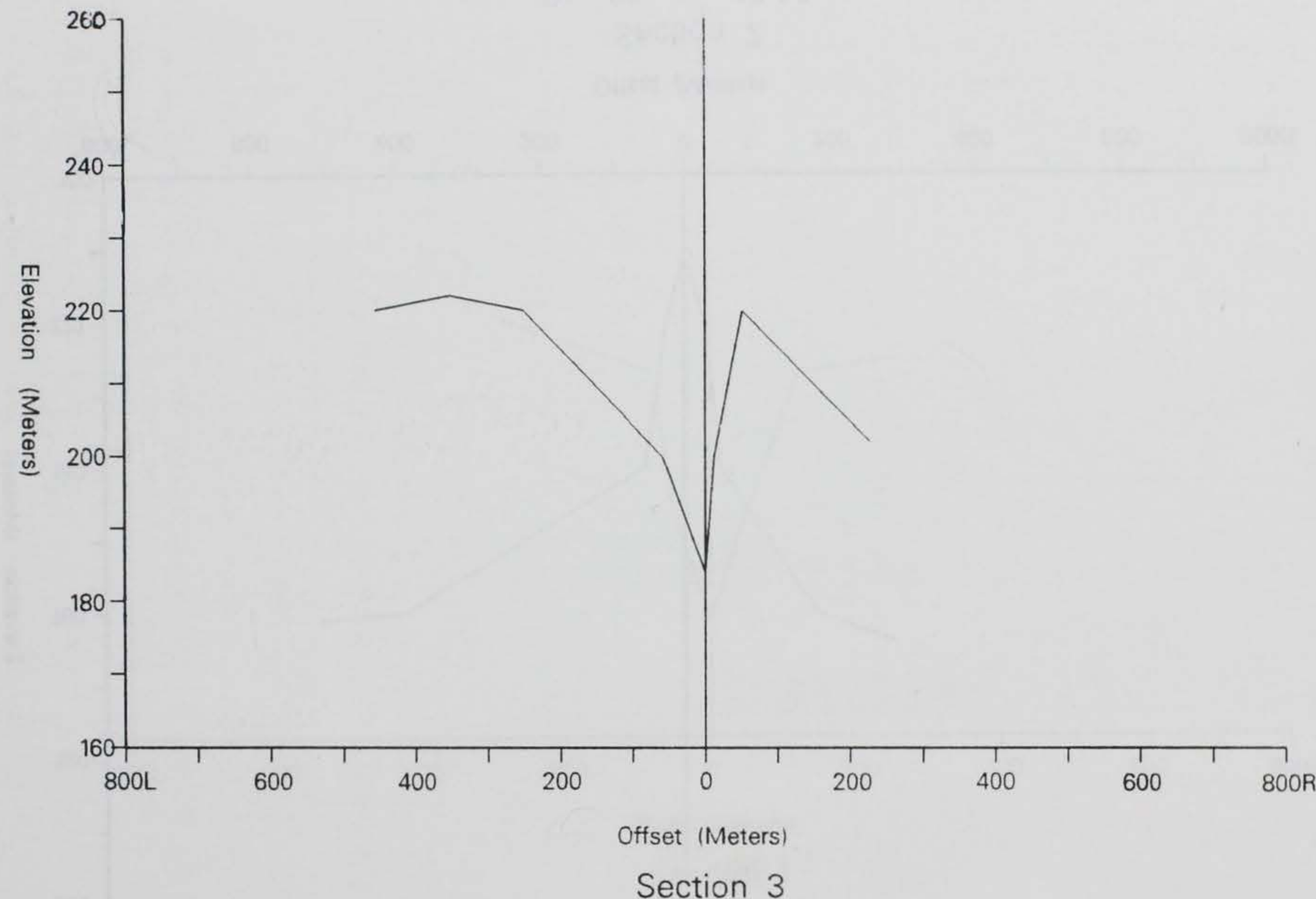

Sta. $50+44.00$

scale $100 \mathrm{~m} / \mathrm{cm}$

Figure 11. Cross Section 3 Malbasag River 


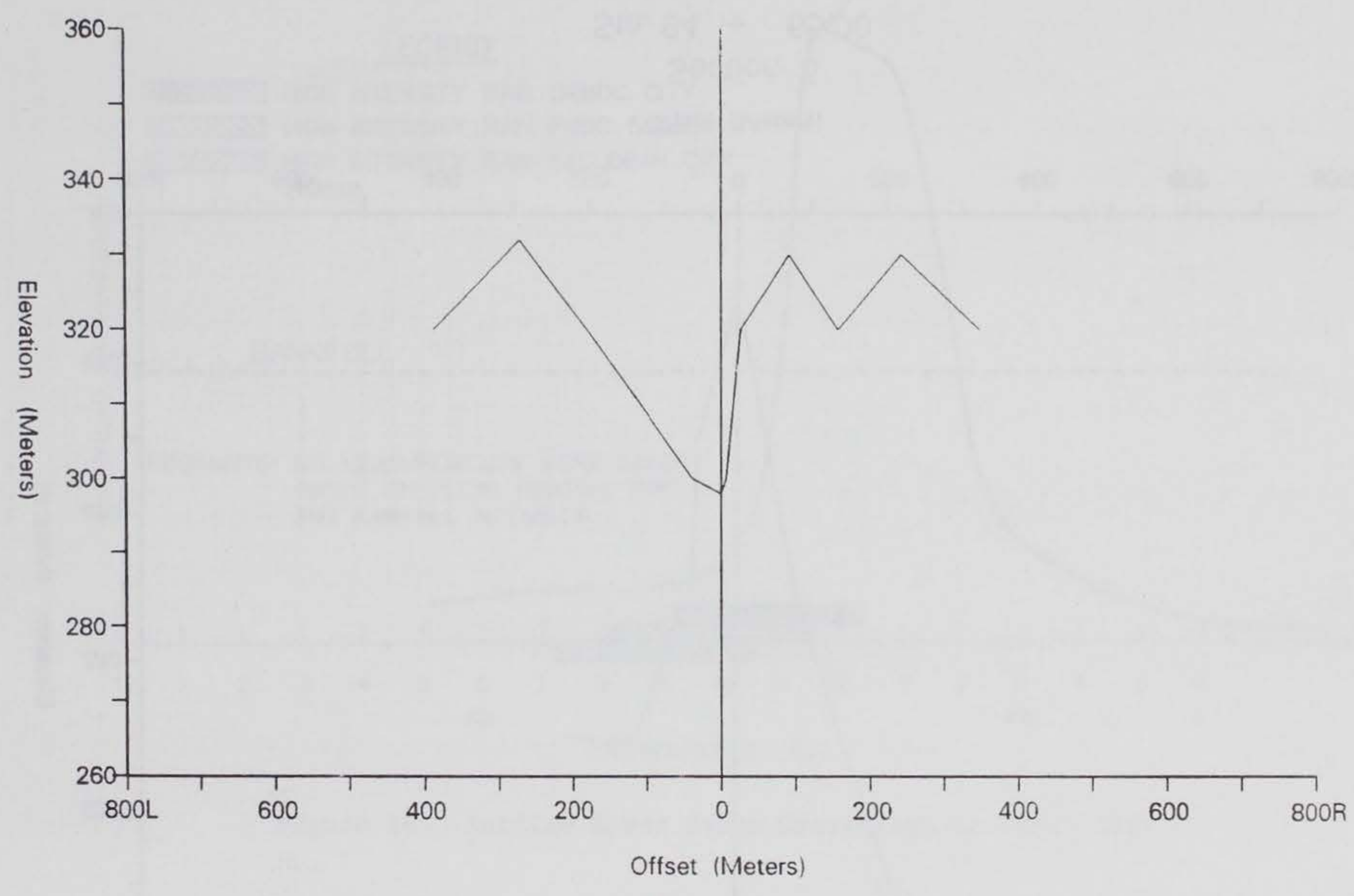

Section 4

Sta. $72+94.00$

Scale $100 \mathrm{~m} / \mathrm{cm}$

Figure 12. Cross Section 4 Malbasag River 


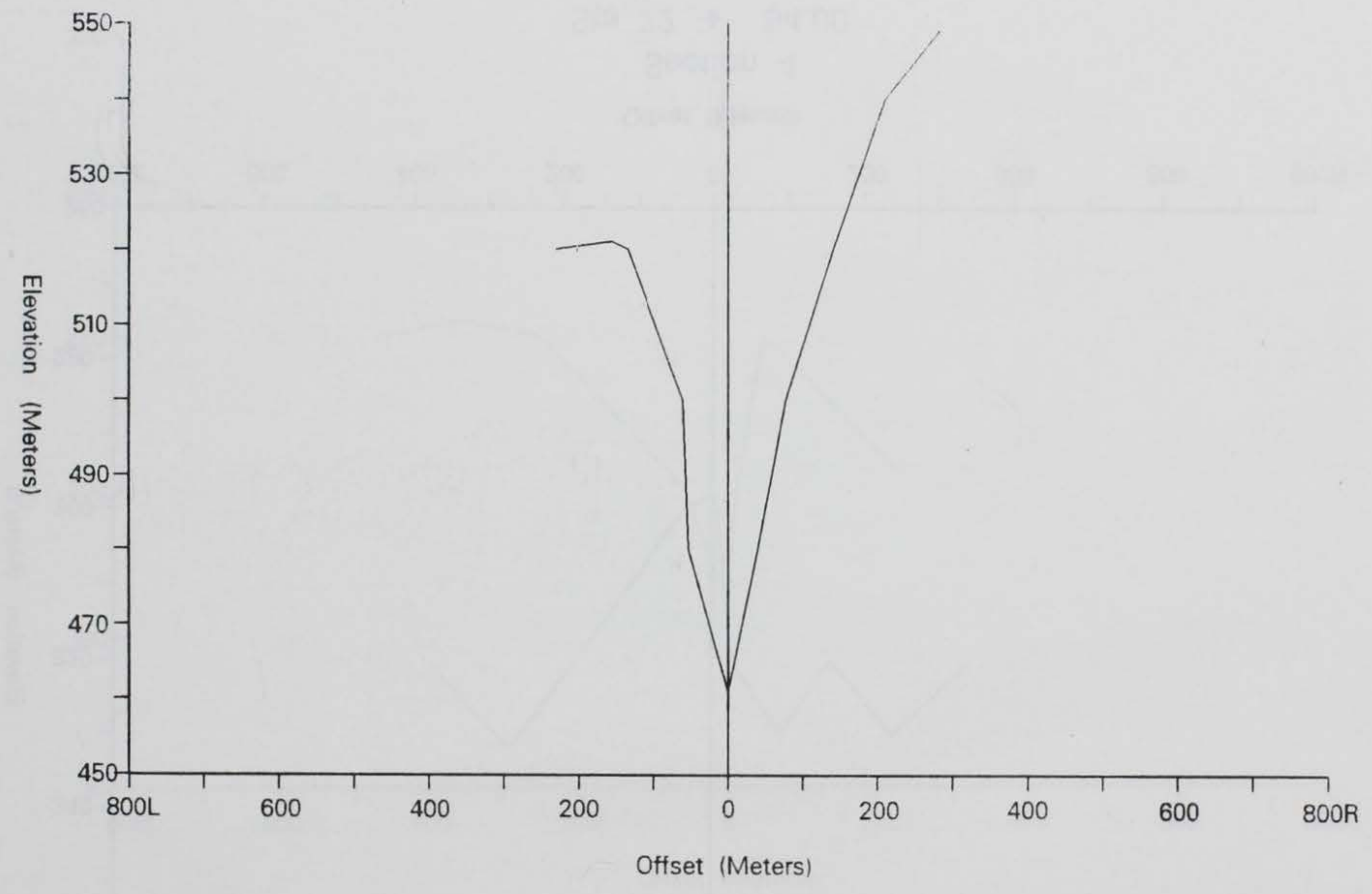

Section 5

Sta. $94+65.00$

Scale $100 \mathrm{~m} / \mathrm{cm}$

Figure 13. Cross Section 5 Malbasag River 


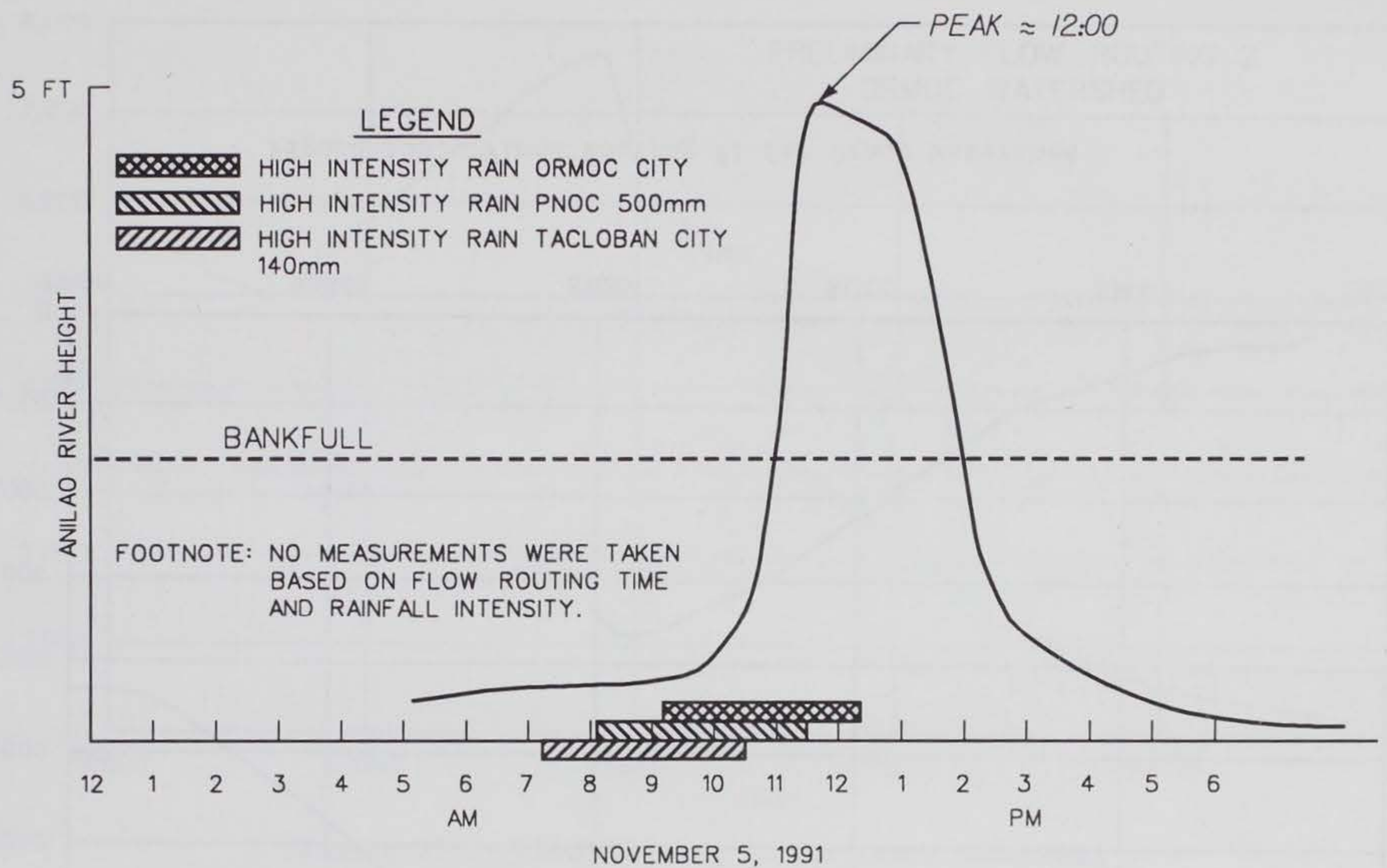

Figure 14. Antilao River Stage Hydrograph at Ormoc City 


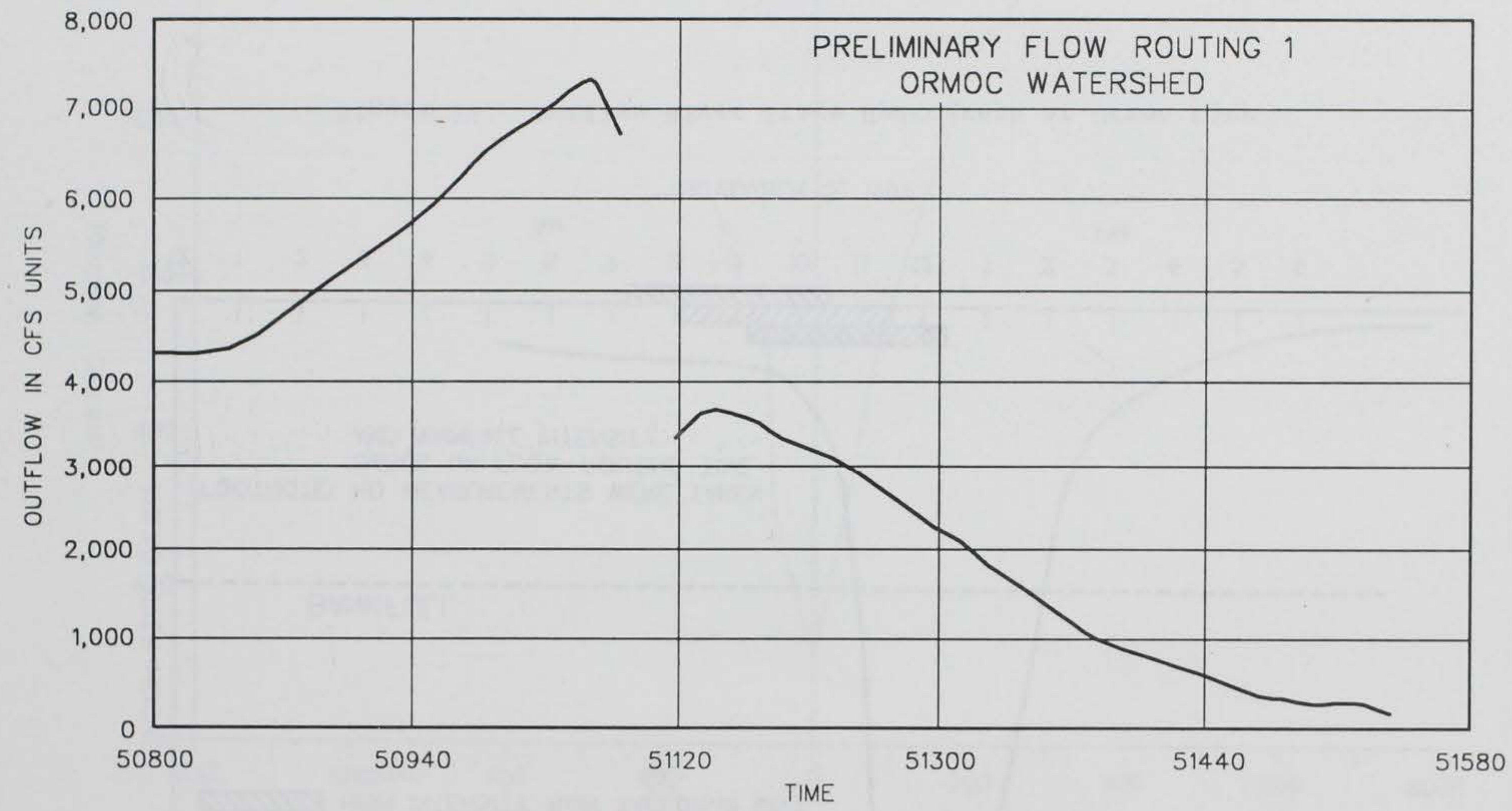

Figure 15a. Flood Routing 非 for Ormoc Watershed 


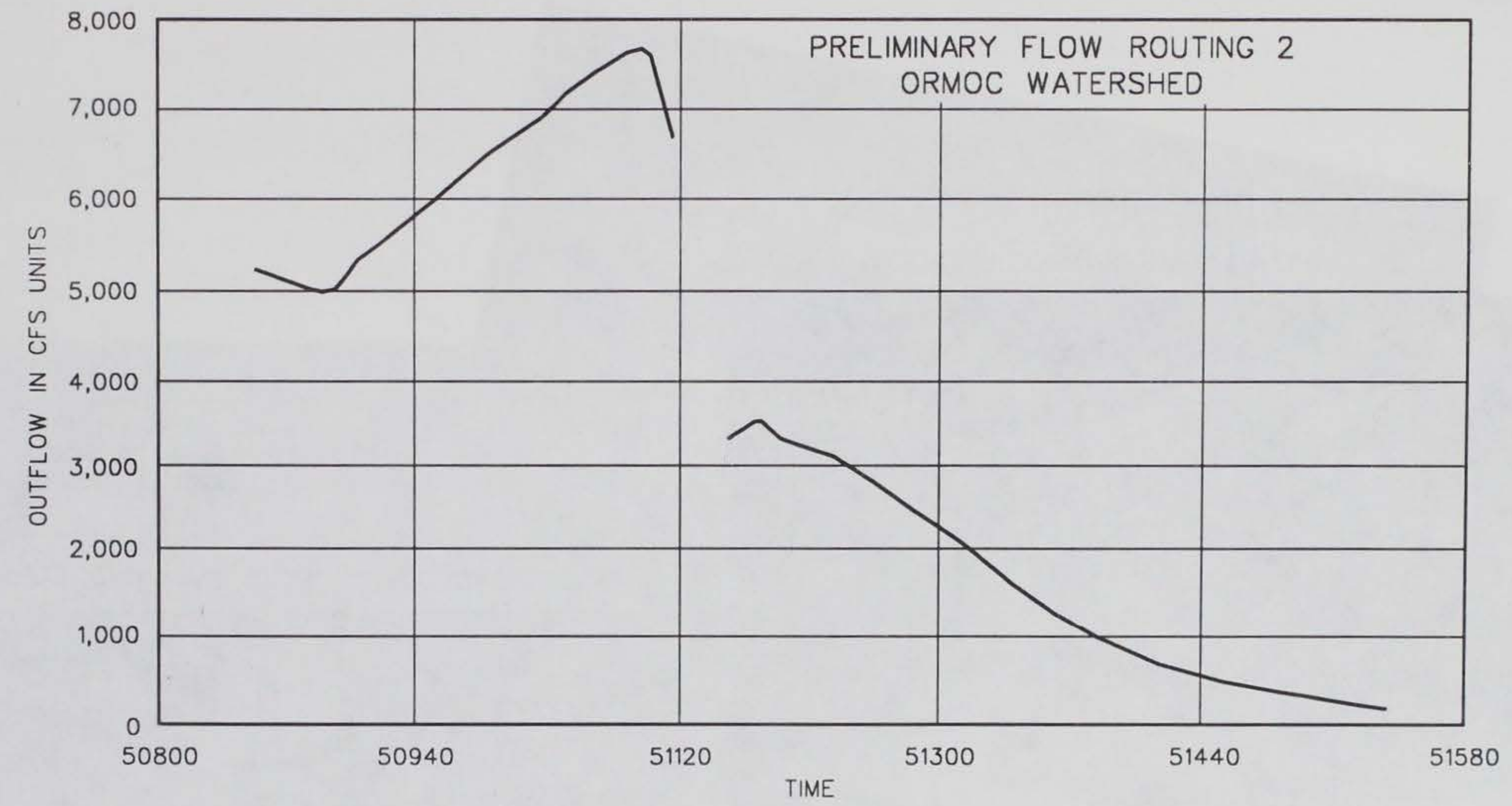

Figure 15b. Flood Routing 非 for Ormoc Watershed 


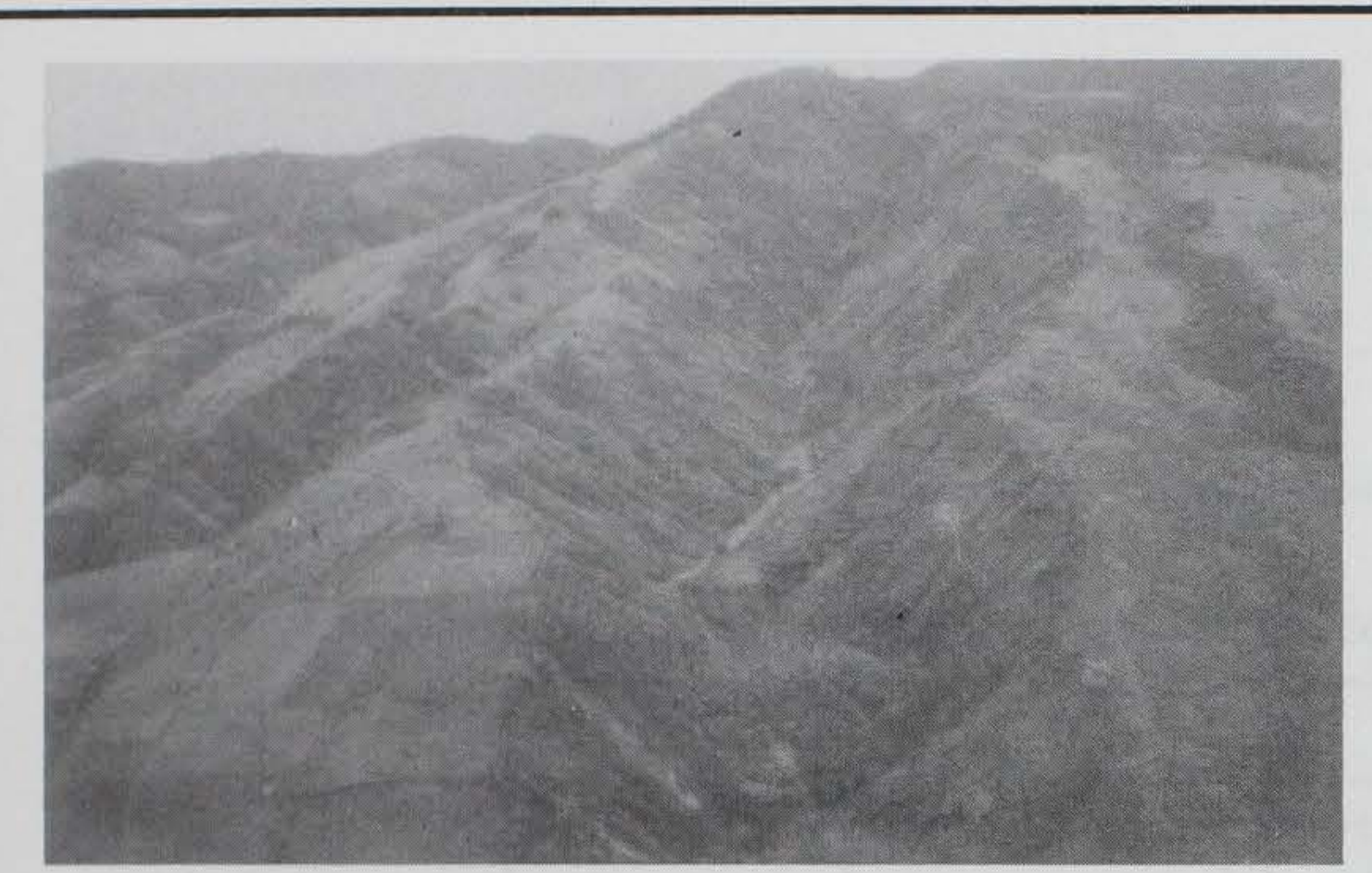

a. UPPER DRAINAGE BASIN ORMOC WATERSHED ANTILAO RIVER

NOTE: CHANNEL INCISION

LANDSLIDE DEPTH AND LENGTH

STREAM SIDE SLOPES

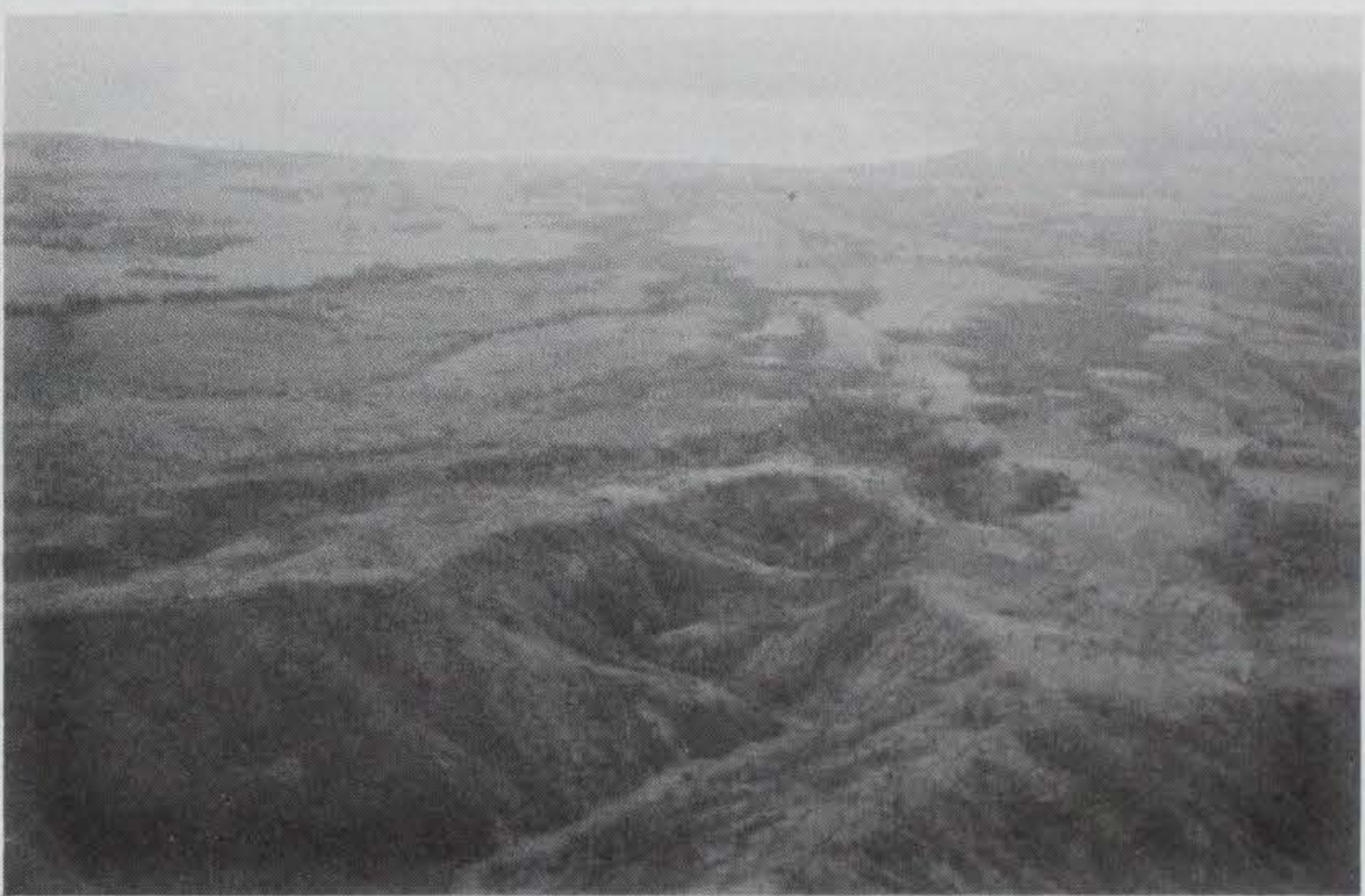

b. LOOKING DOWN SYSTEM TO ORMOC CITY

NOTE: DENDRITIC CHANNEL PATTERN 


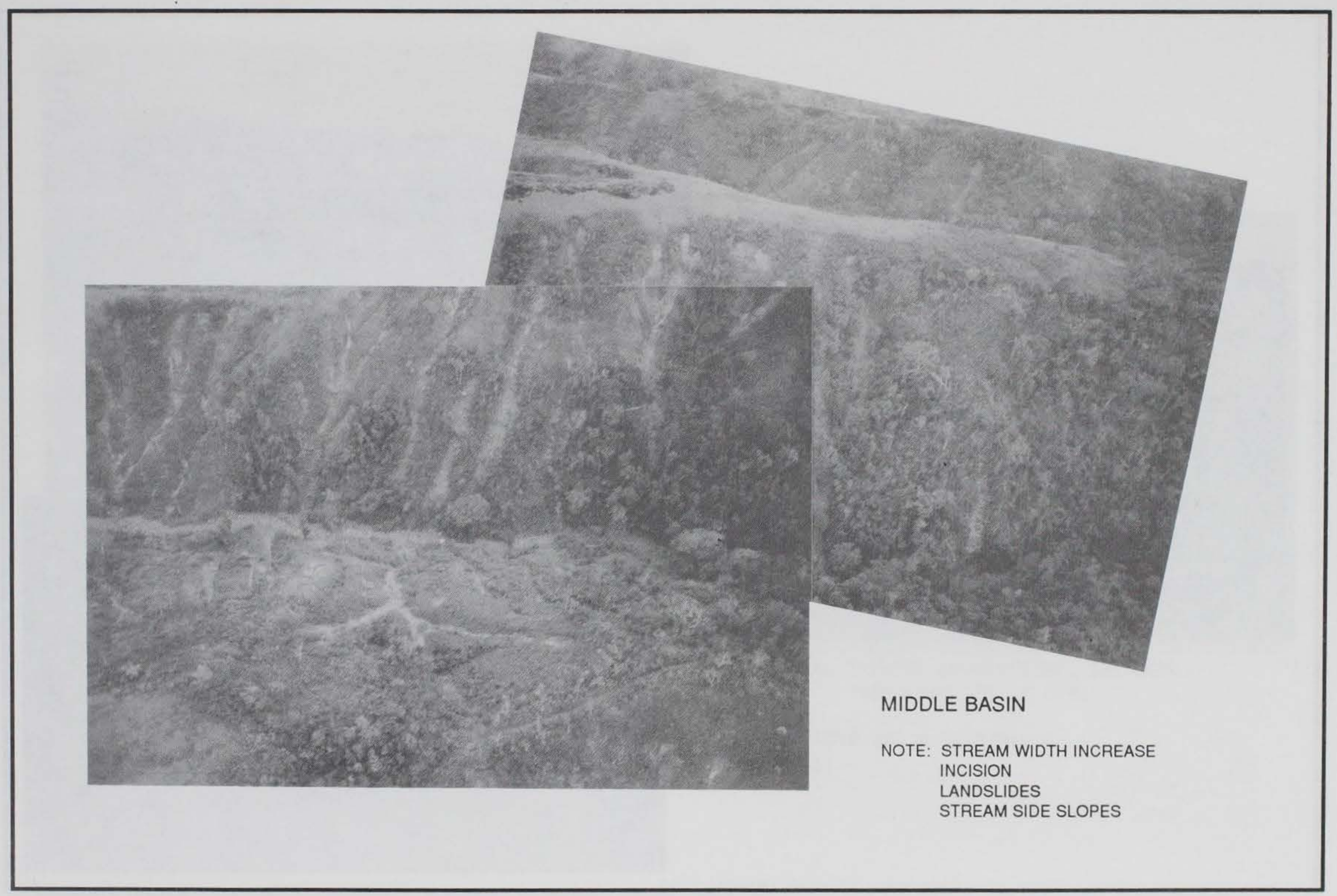

PHOTO PLATE 2 


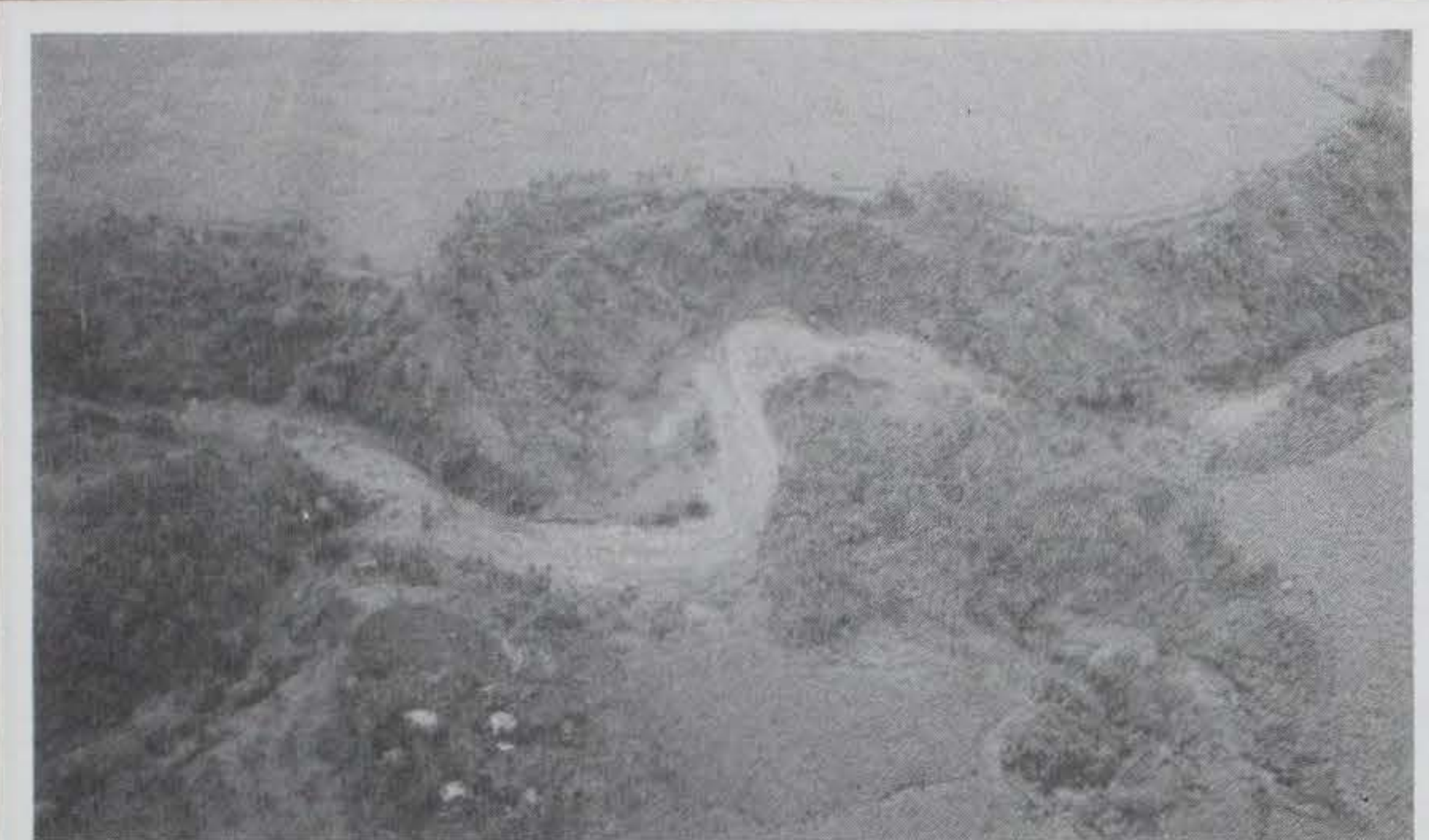

$\omega$

LOWER BASIN

NOTE: CHANNEL MEANDERS

INCISION

DECREASE IN CHANNEL SIDE SLOPE

REDUCTION IN LAND SLIDE OCCURRENCE

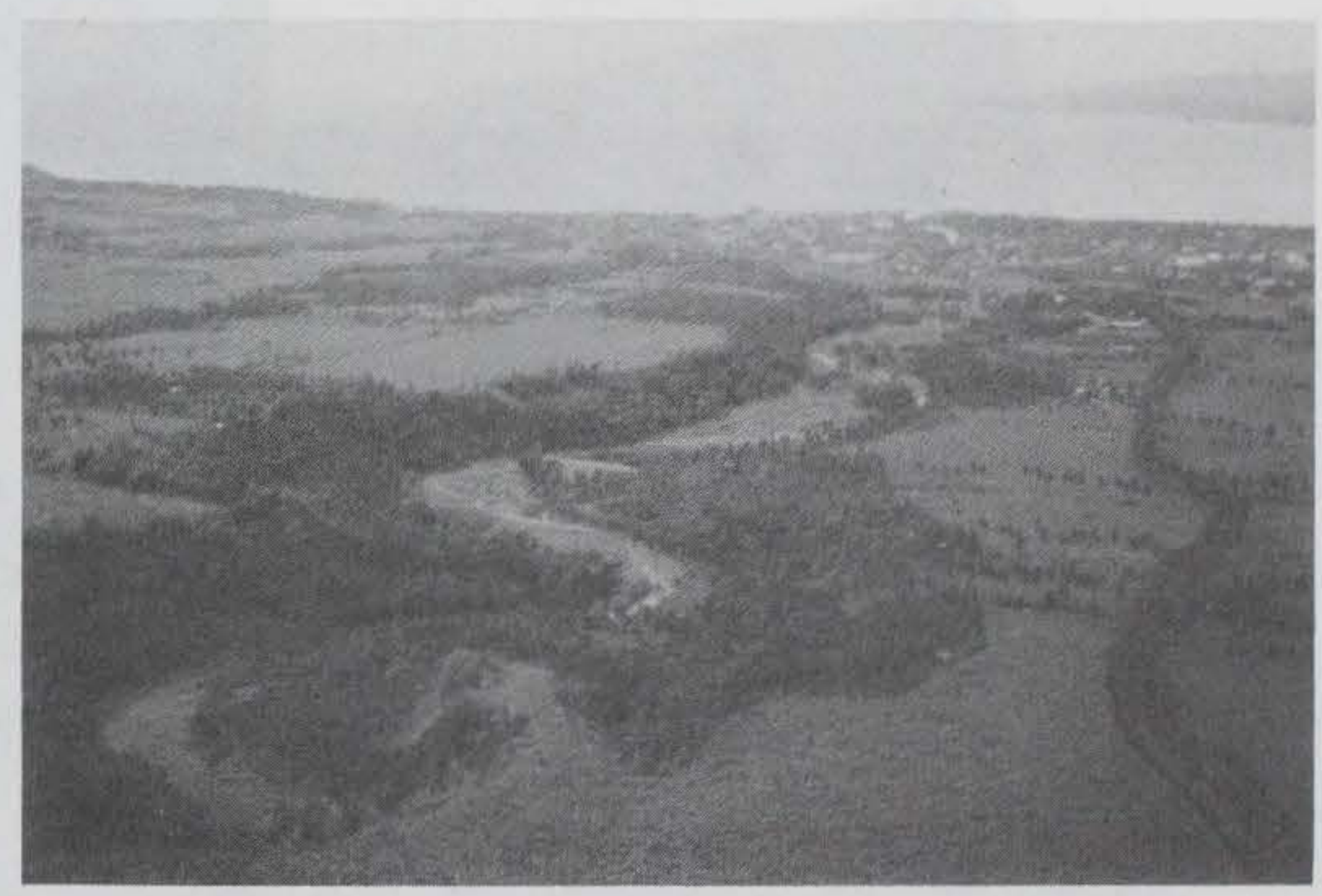

PHOTO PLATE 3 


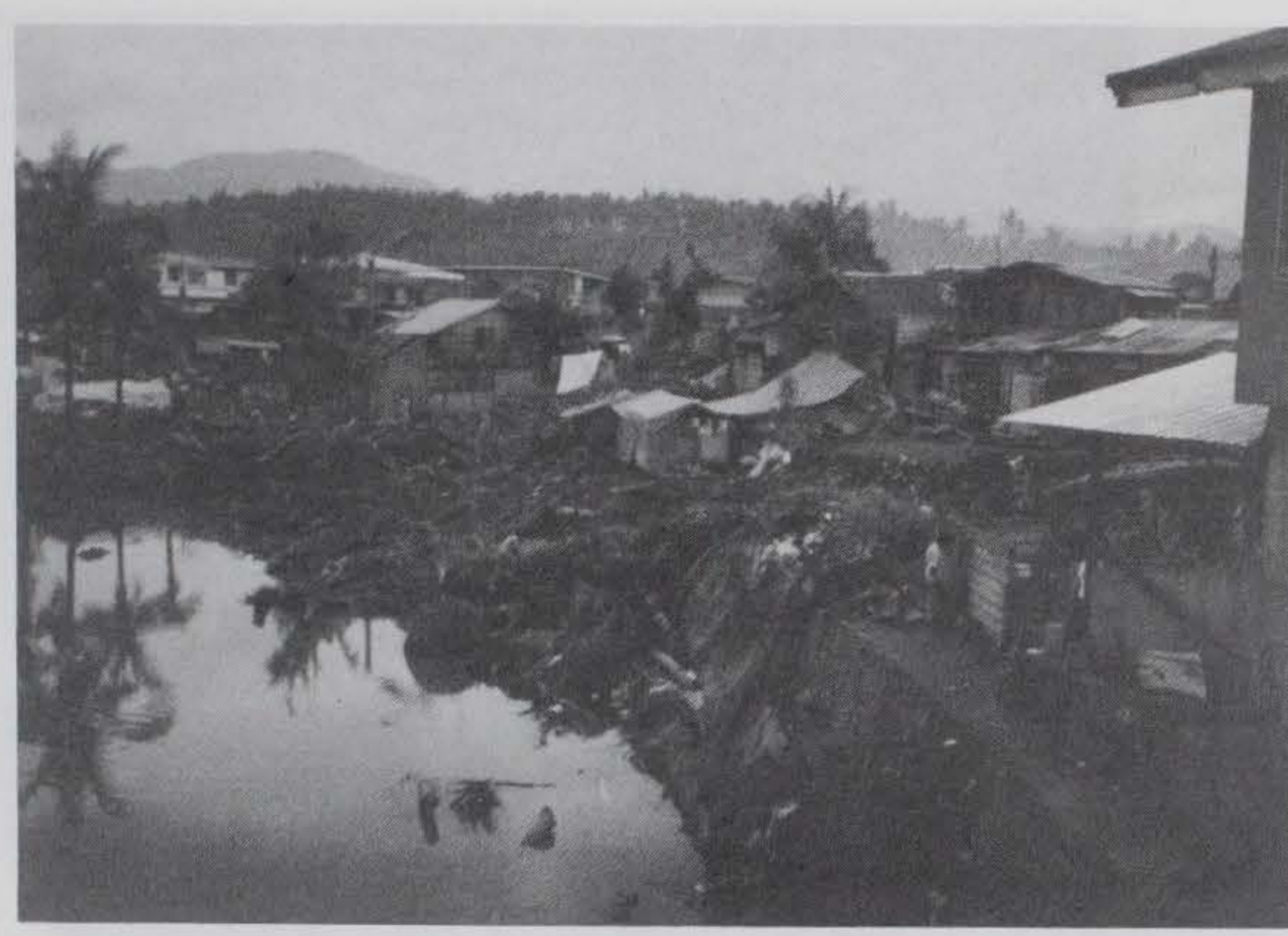

a. WOODY DEBRIS DEPOSITION AREA UPSTREAM OF ANTILAO RIVER BRIDGE

NOTE: 1. CHANNEL MAKES $90^{\circ}$ BEND AT THIS LOCATION

2. FLOW MOMENTUM DIRECTED TO

RIGHT OF PHOTO WHICH IS

PROBABLE 1ST OVERFLOW ZONE

INTO CITY

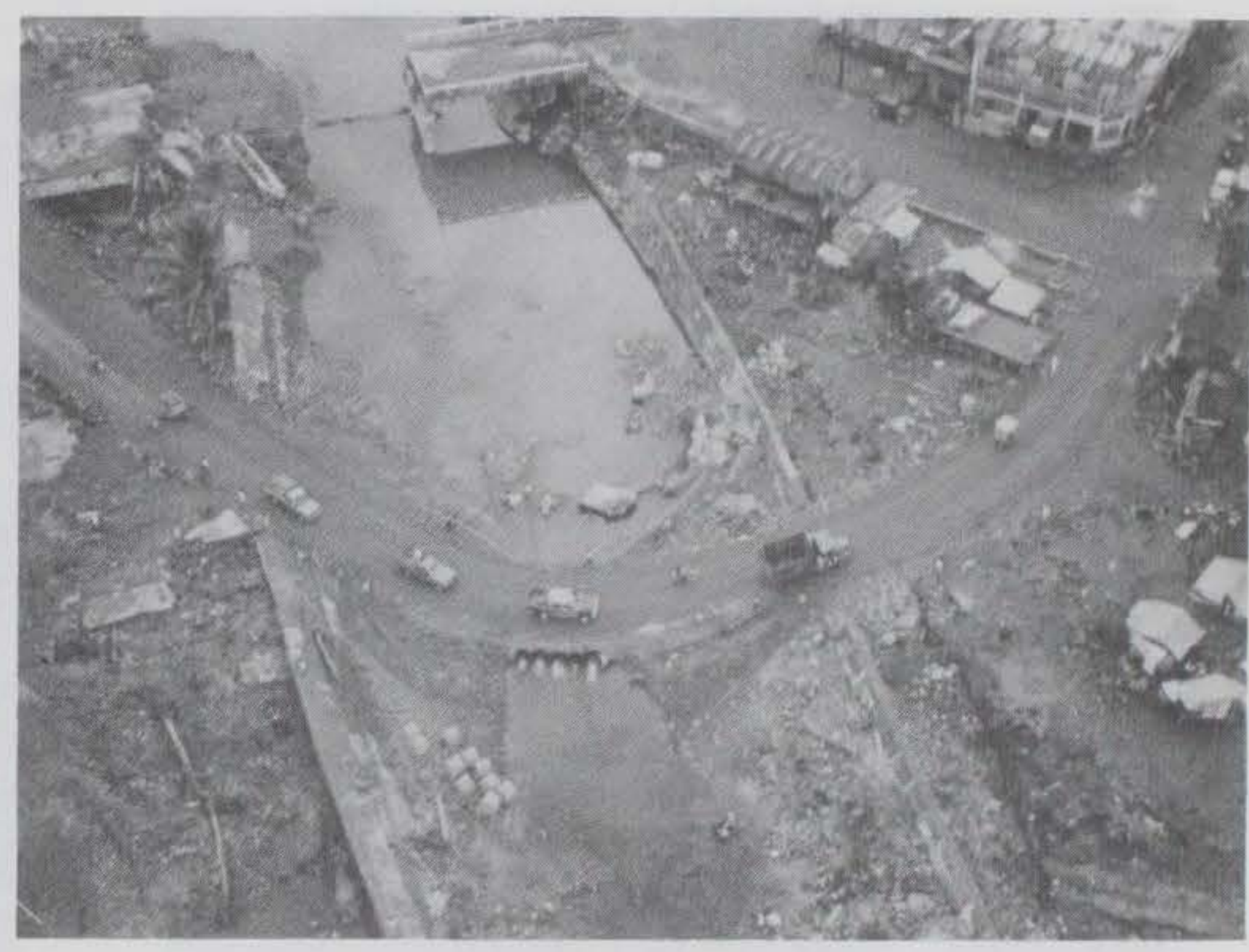

b. TYPICAL CHANNELIZED SECTION THROUGH ORMOC CITY

NOTE: FAILED RIVER BRIDGE 


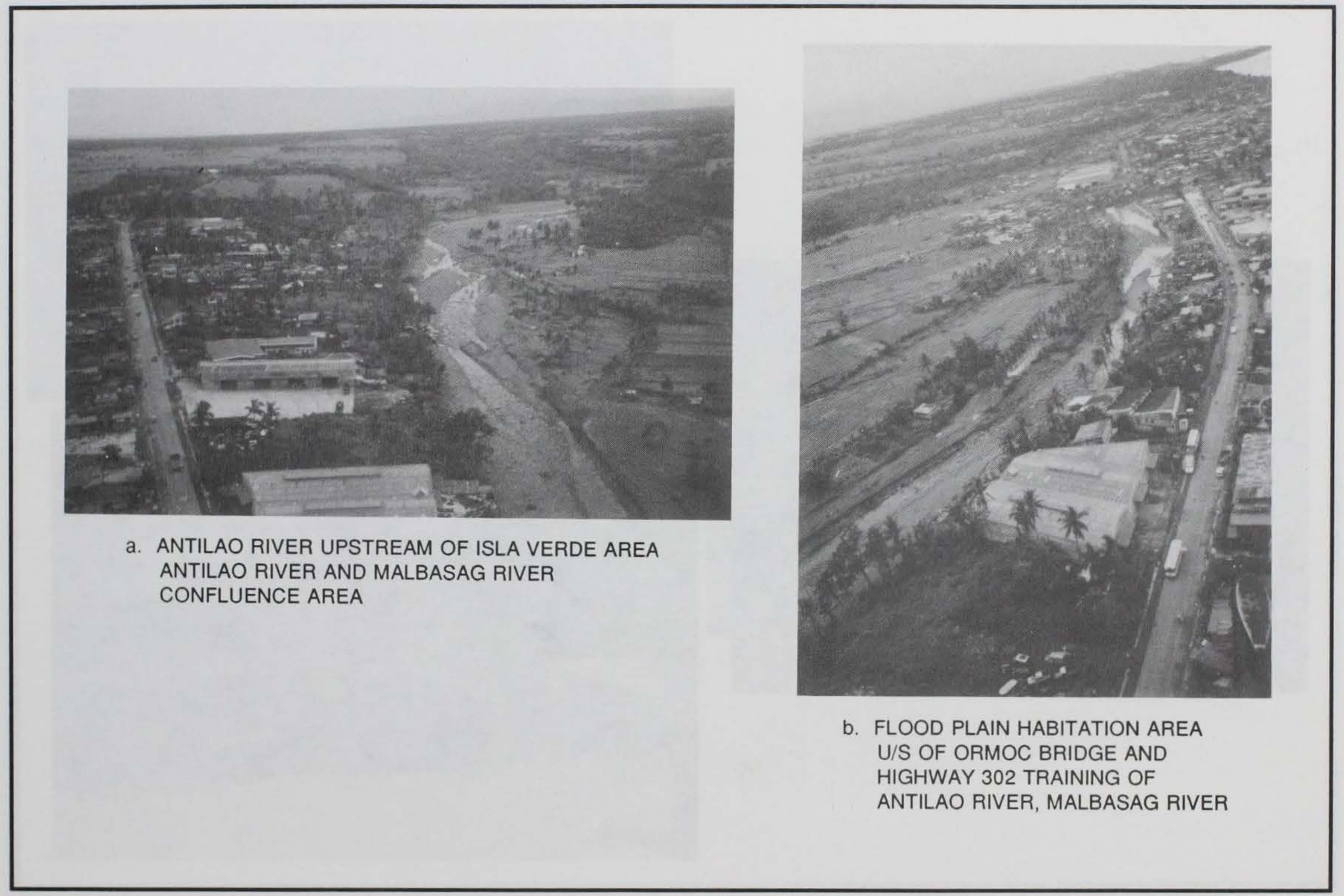

PHOTO PLATE 5 


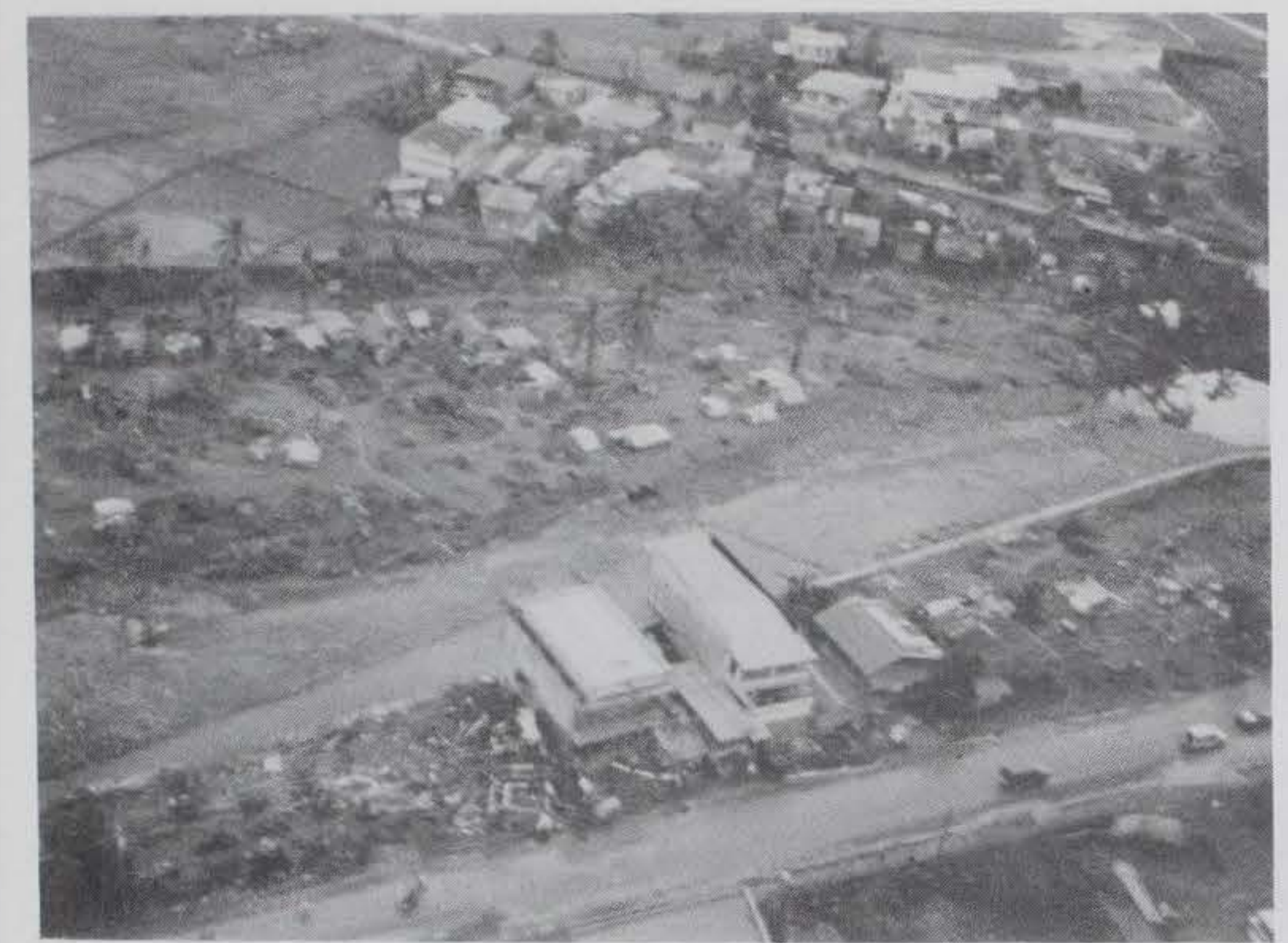

a. FLOOD PLAIN REHABITATION ISLA VERDE AREA

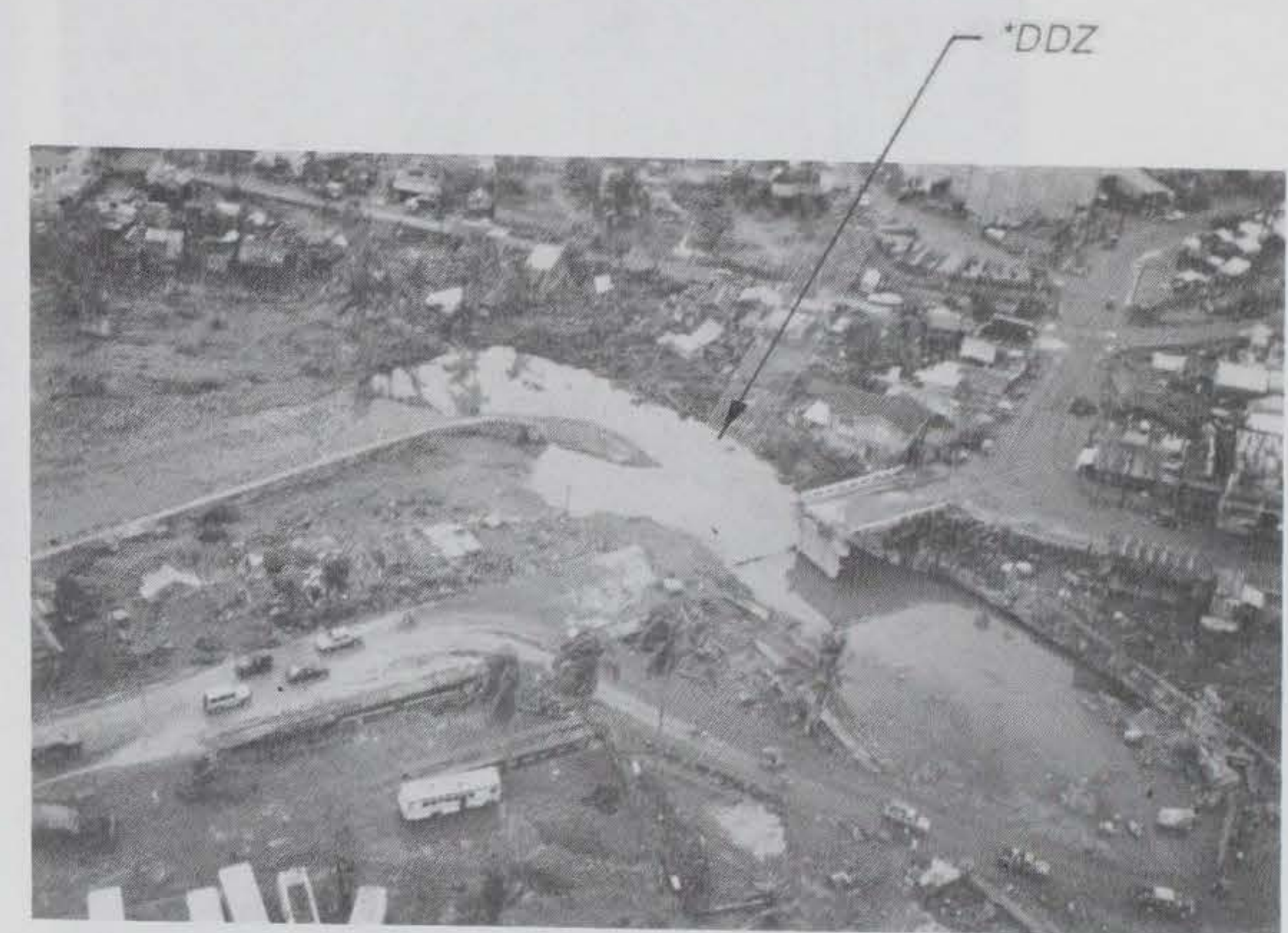

b. ANTILAO BRIDGE AT ORMOC

NOTE: CHANNELIZATION DOWNSTREAM OF FAILED BRIDGE STRUCTURE $90^{\circ} \mathrm{CHANNEL} \mathrm{BEND}$ DEBRIS DEPOSITION ZONE

$\cdot D D Z=$ DEBRIS DEPOSITION ZONE 
TREE BLOW DOWN UPPER ORMOC WATERSHED

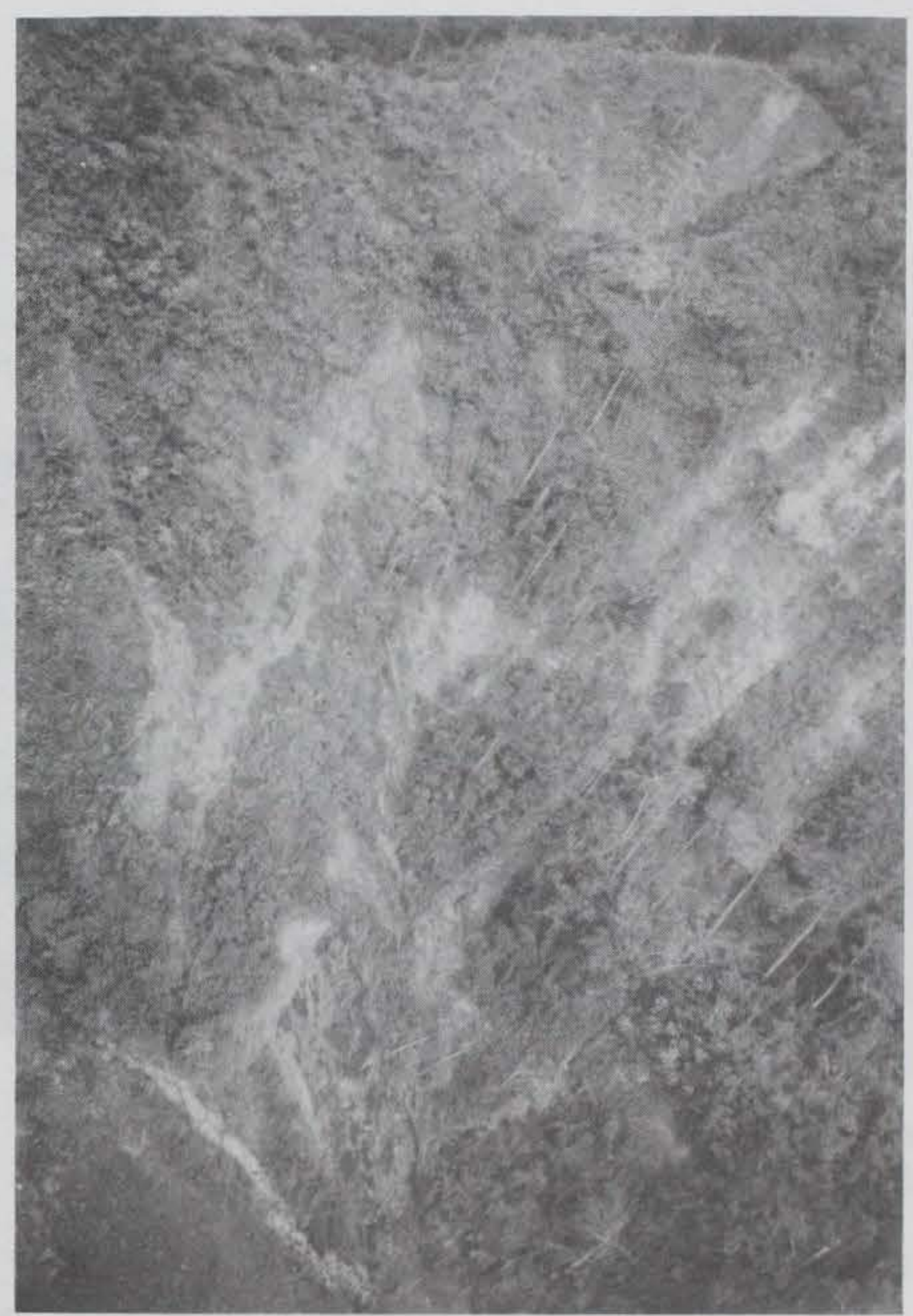




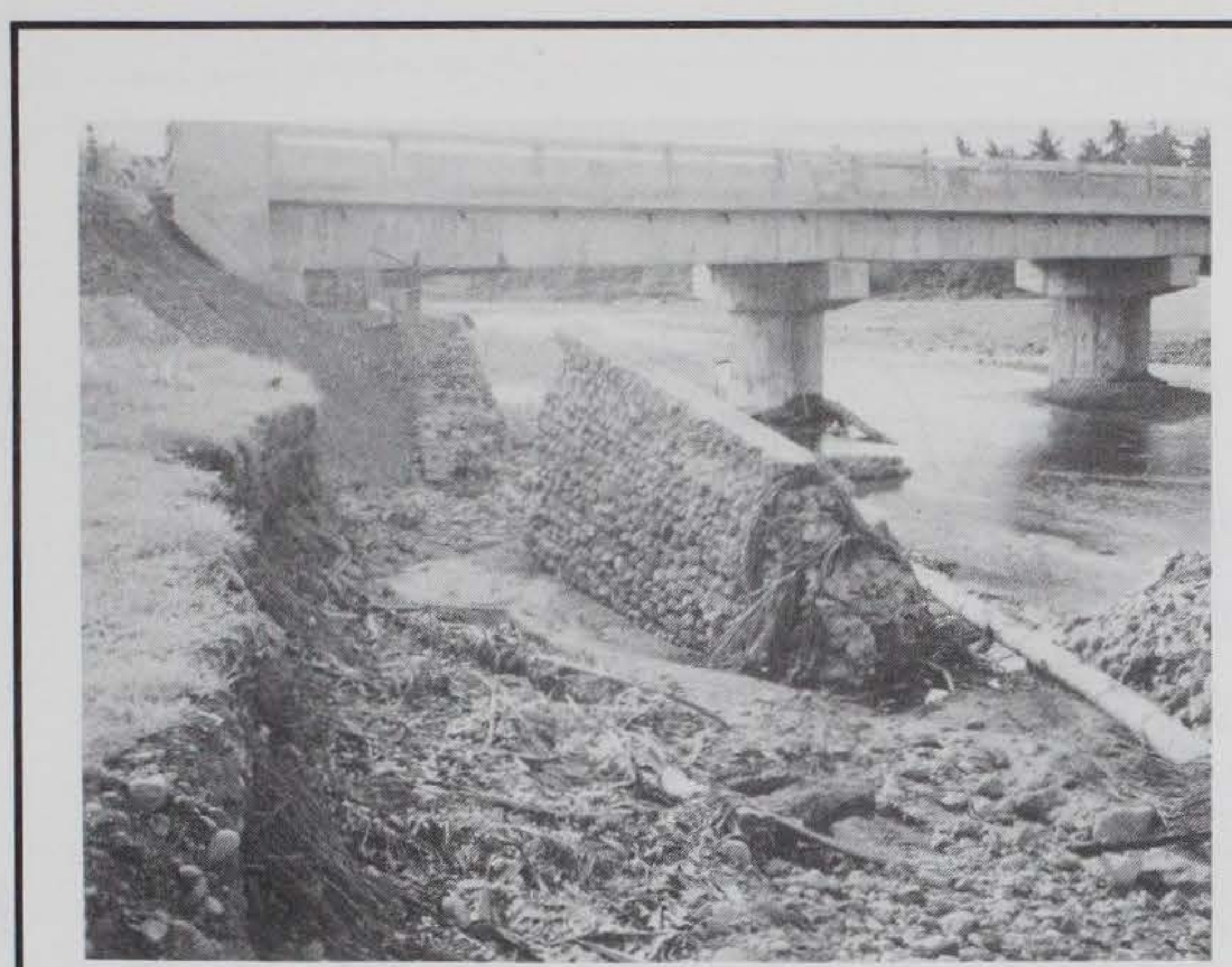

a. BRIDGE FAILURE PALANAS BRIDGE

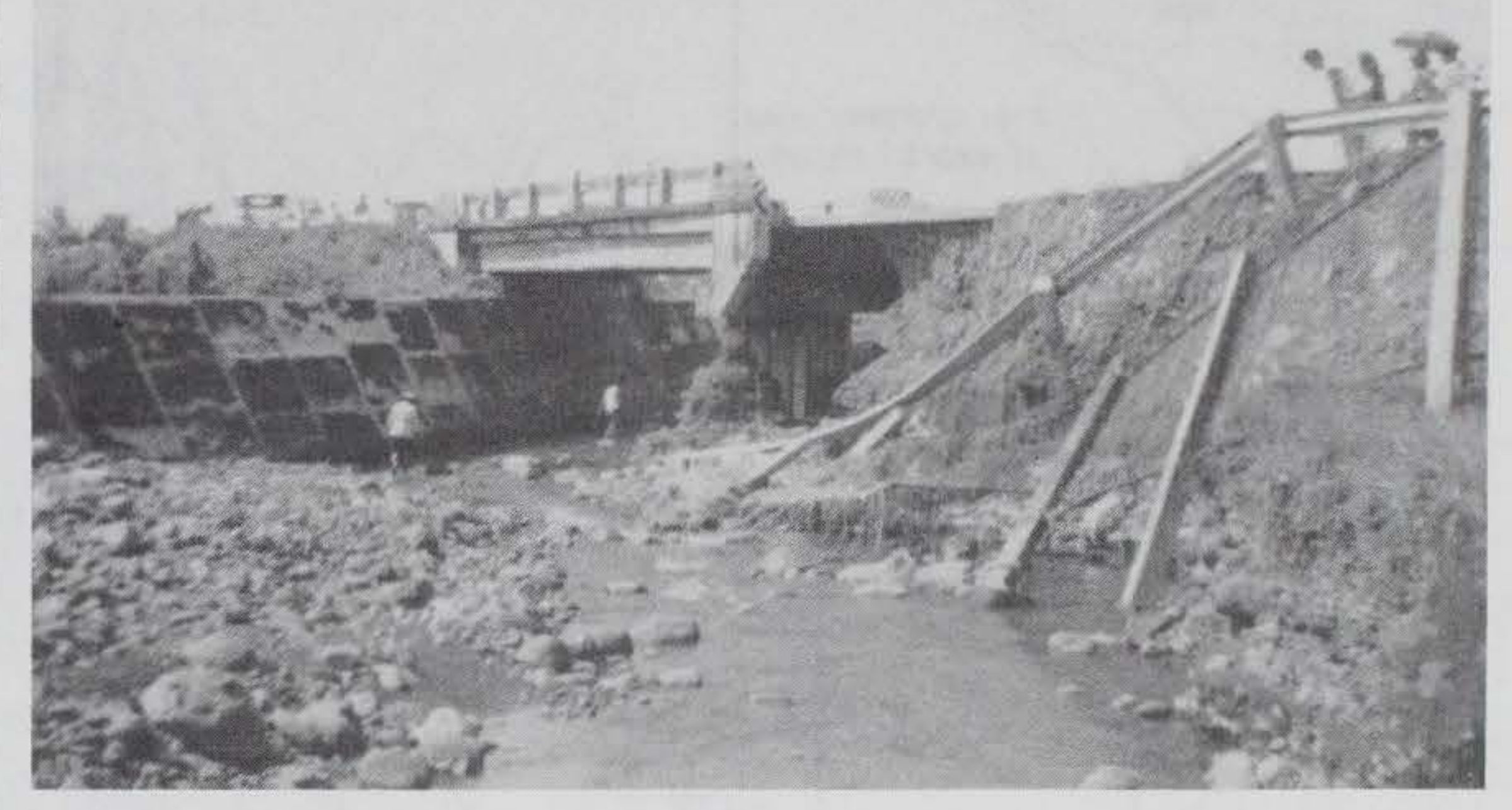

b. BRIDGE FAILURE CALGIGA-A BRIDGE 


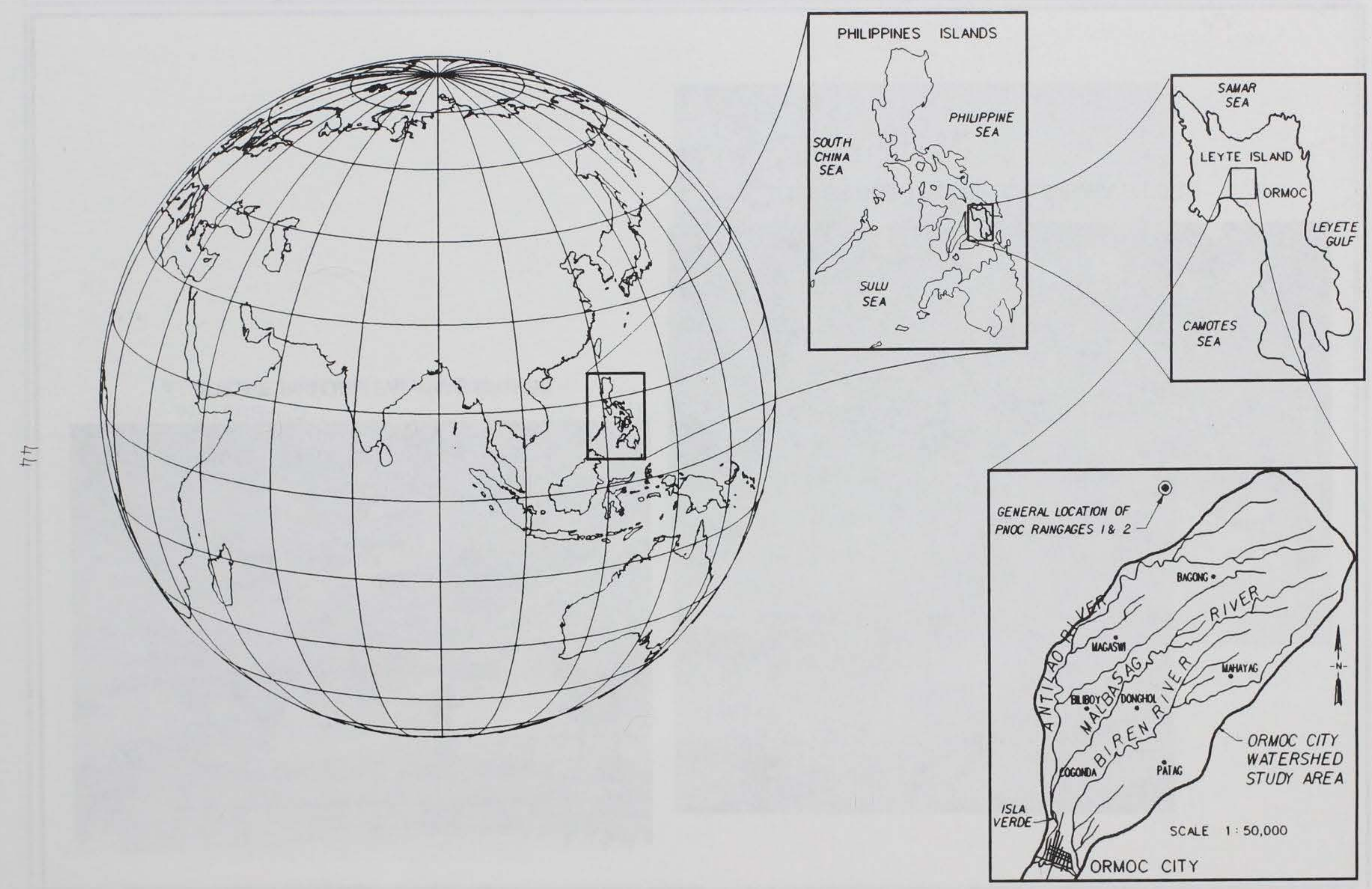

Map 1. Location Map, Ormoc Watershed, The Phillippines 




Map 2. Ormoc City Area Map, Two Rivers and Flooded Areas 


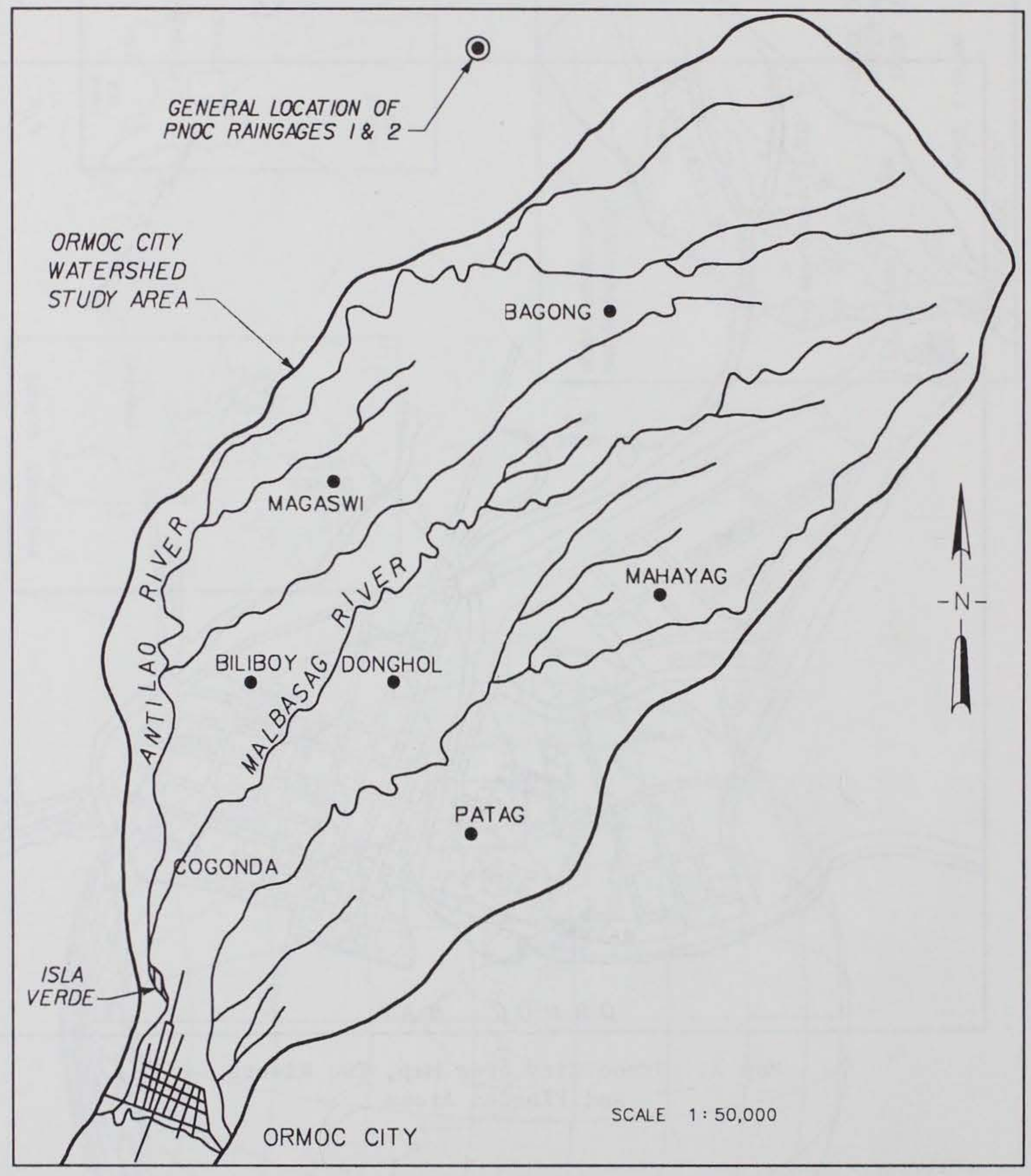

Map 3. Ormoc Watershed 


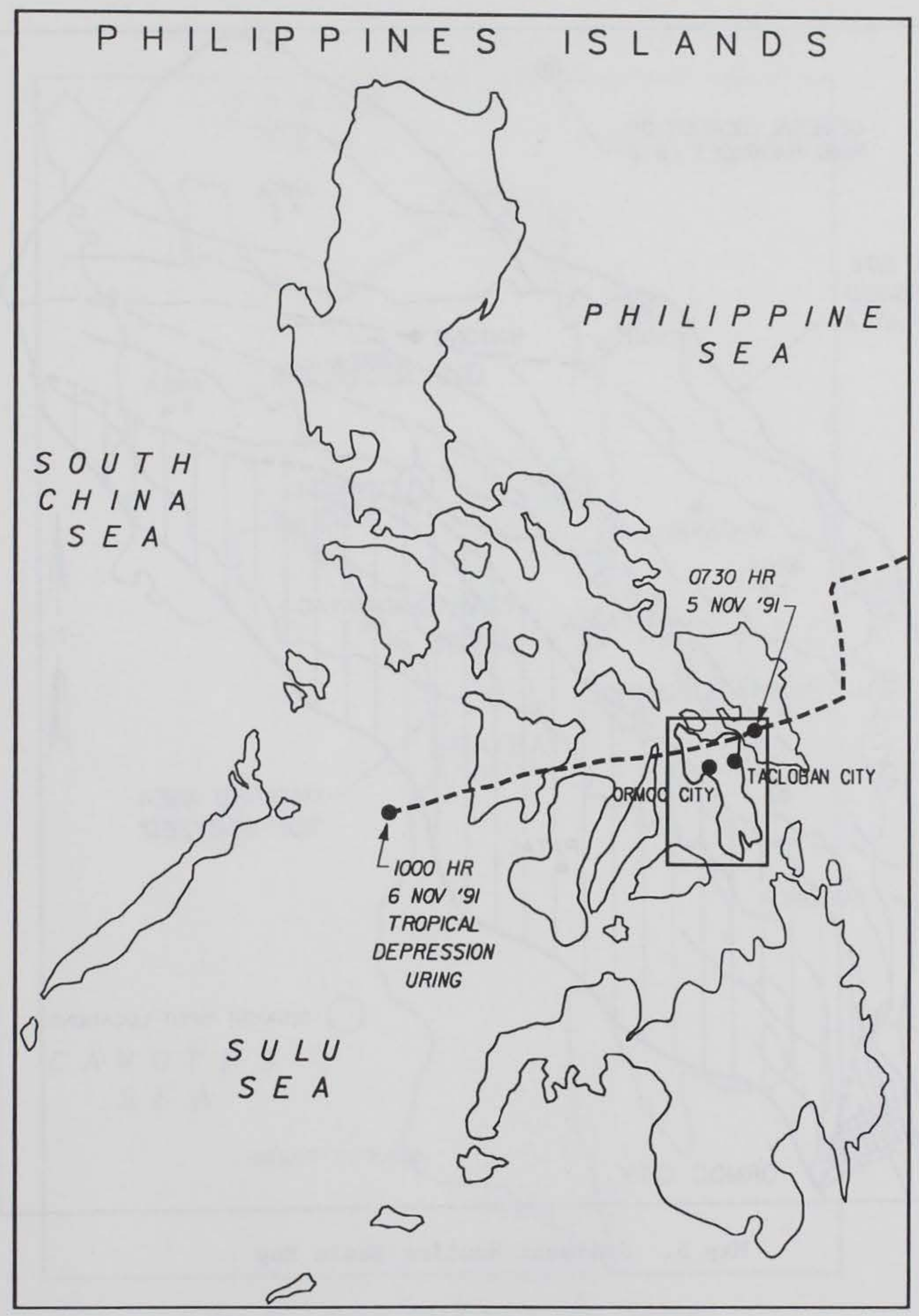

Map 4. Storm Track for Typhoon URING 


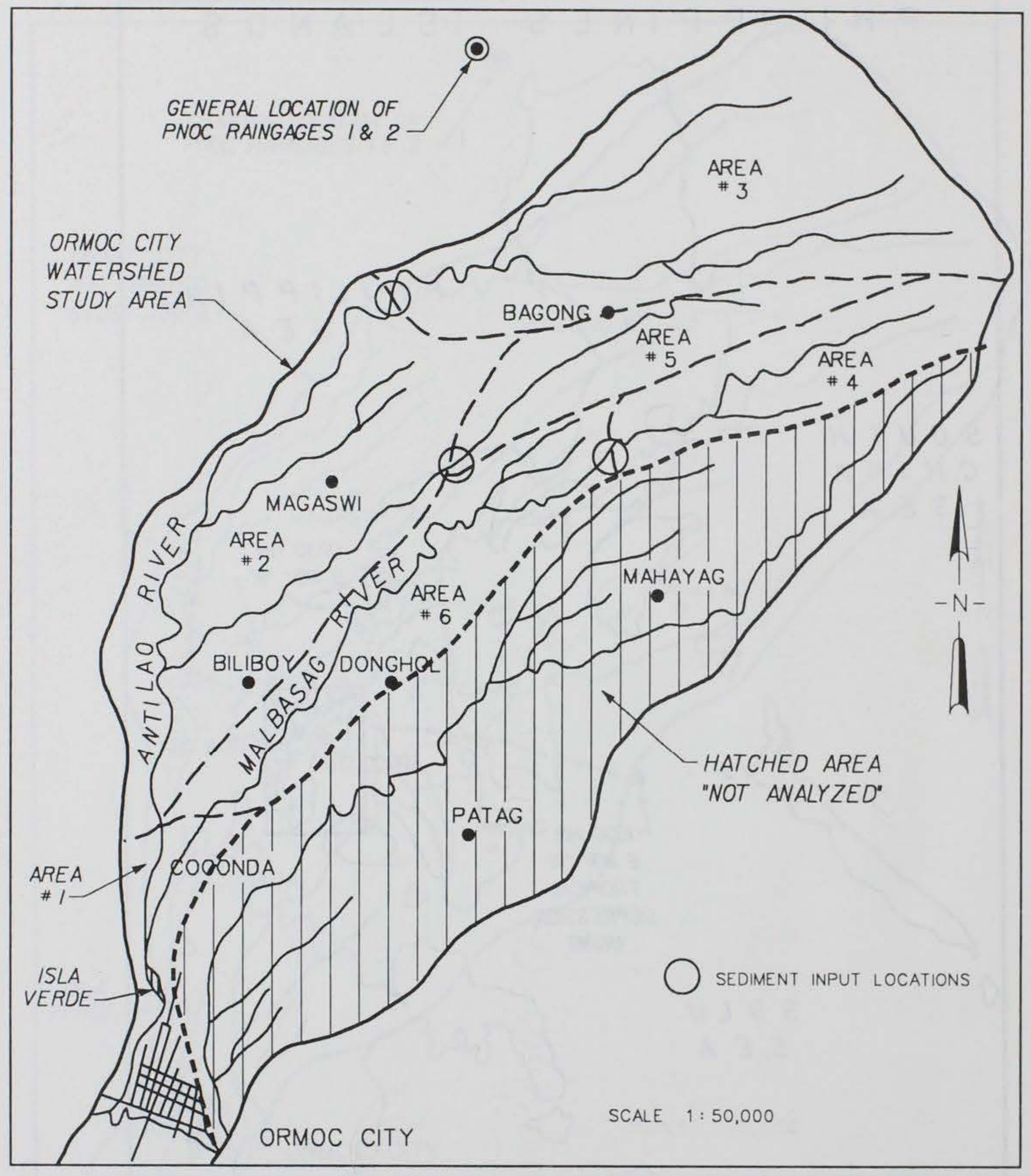

Map 5. Sediment Routing Basin Map 


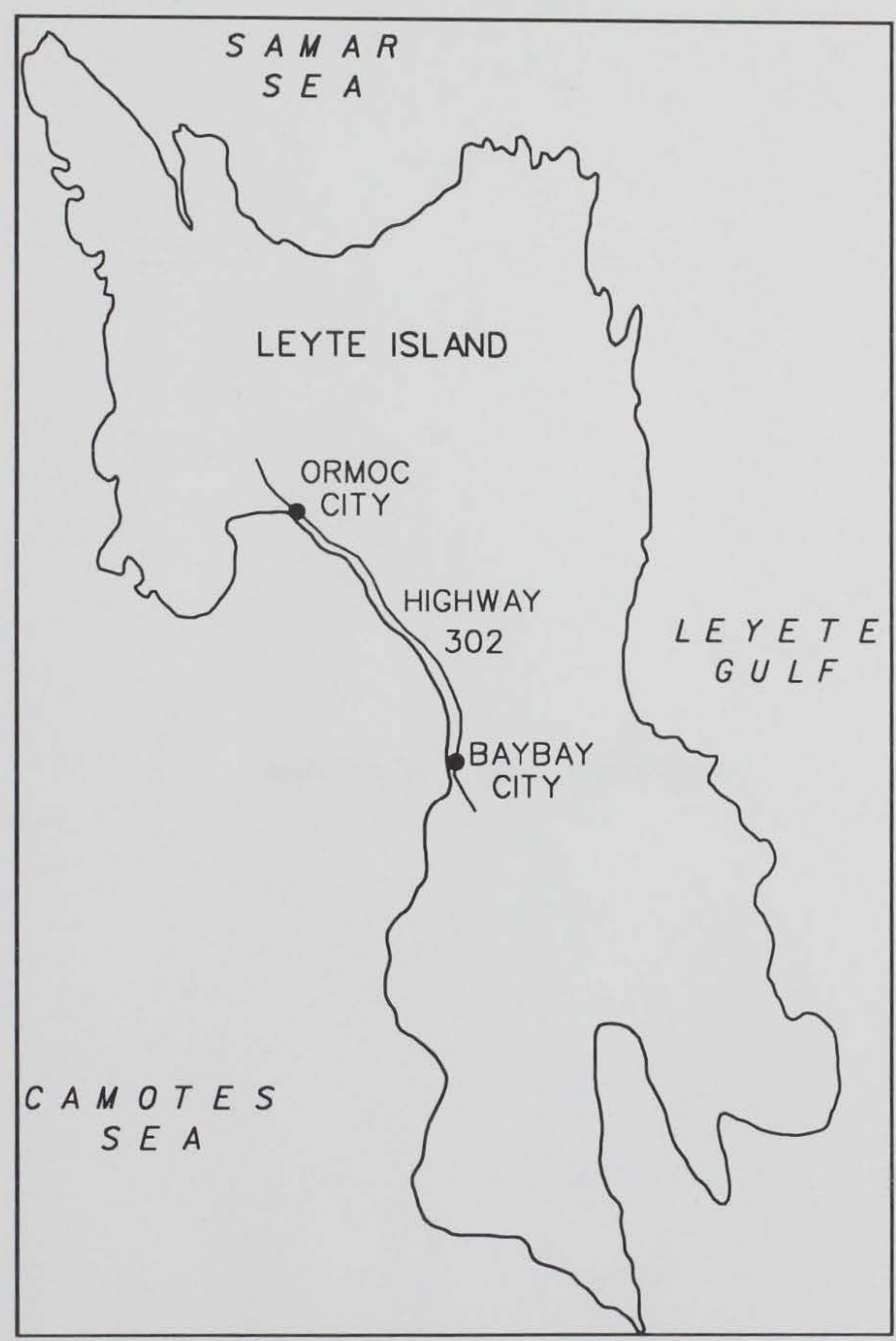

Map 6. Ormoc City to Baybay Leyte Coastal Highway No. 302 
Appendix A: List of Contacts 
Vicente Paragas

\section{Rosalio Goze}

John Sturnes

Bob Vergara

Abelardo M. Monge, Jr.

Pacifico G. Mendoza, Jr.

Eriverto V. Loreto

Carment L. Cari

Ruben Penserga

Ramon Omega

Leonardo A. Nunez

Fortunato Dejoras

Romulo M. del Rosario

Vicente Yulo

Minni Dilgo

Janparralla
Regional Technical Director, Department of Environment and Natural Resources

Regional Executive Director, Department of Environment and Natural Resources

U.S. AID Office of Capital Projects, U.S. State Department

U.S. AID Office of Capital Projects, U.S. State Department

Assistant Regional Director for Services, Department of Public Works and Highways

Regional Director, Department of Public Works and Highways

Congressman, 5th District, Leyte

Mayor, Baybay, Leyte

City Engineer, Ormoc, Leyte

District Engineer, Leyte 2, Department of Public Works and Highways

Director, Bureau of Maintenance, Department of Public Works and Highways

Administrator, Office of Civil Defense

Undersecretary, Bureau of Maintenance, Department of Public Works and Highways

Third Leyte Engineering District, Assistant District Engineer

Philippine National Oil Company, Assistant Service Manager

Weather Data 


\section{ENGINEERING OFFICER \\ USAID/Philippines}

Date: $\quad 05$ December 1991

To: $\quad$ File

Subject: ORMOC DISASTER

Corps of Engineers

Revised agenda for evaluation team:

05 DEC $912250 \mathrm{hrs}$

05 DEC $912320 \mathrm{hrs}$

05 DEC $912350 \mathrm{hrs}$

06 DEC $910845 \mathrm{hrs}$

06 DEC $910900 \mathrm{hrs}$

06 DEC $911100 \mathrm{hrs}$

06 DEC $91 \quad 1330 \mathrm{hrs}$

06 DEC $91 \quad 1400 \mathrm{hrs}$

06 DEC $91 \quad 1530$ hrs

06 DEC $91 \quad 1600 \mathrm{hrs}$

08 DEC $911430 \mathrm{hrs}$

08 DEC $911500 \mathrm{hrs}$

08 DEC $91 \quad 1600 \mathrm{hrs}$

08 DEC $91 \quad 1705$ hrs

09 DEC 910830 hrs

09 DEC 911600 hrs

10 DEC $910830 \mathrm{hrs}$

10 DEC $911500 \mathrm{hrs}$

10 DEC $91 \quad 1805$ hrs

10 DEC $91 \quad 1940 \mathrm{hrs}$

11 DEC 91

12 DEC 91

13 DEC $910800 \mathrm{hrs}$

13 DEC 910815 hrs

13 DEC $910830 \mathrm{hrs}$

13 DEC $911030 \mathrm{hrs}$
Team arrives NAIA

Team departs NAIA for Sheraton Team arrives at Sheraton

USAID vehicle picks up Team at Sheraton for travel to RMC

Team arrives at RMC and meets with USAID technical staff

Team meets with USAID Director

Team departs RMC for DPWH

Team meets with DPWH Undersecretary

Team departs DPWH for Sheraton

Team arrives at Sheraton

USAID vehicle picks up Team at

Sheraton for travel to Manila domestic airport

Team arrives at Manila domestic airport

Team departs Manila via PAL

Team arrives Tacloban

Team departs Tacloban for Ormoc via GOP helicopter

Team departs Ormoc for Tacloban via GOP helicopter

Team departs Tacloban for Ormoc via GOP helicopter

Team departs Ormoc for Tacloban via GOP helicopter

Team departs Tacloban via PAL

Team arrives Manila

Team drafts report and prepares for exit briefing

Team drafts report and prepares for exit briefing

USAID vehicle picks up Team at

Sheraton for travel to RMC

Team arrives at RMC and meets with USAID technical staff

Team gives exit briefing at USAID

Team departs RMC for DPWH 
13 DEC 911100 hrs Team arrives at DPWH and gives exic

\section{DEC 911230 hrs Team departs DPWH}

Bob Vargara, a USAID Foreign Service National engineer assigned to the region which includes Ormoc, and John Starnes, USAID Engineering Officer, will accompany the team to Ormoc. USAID/Manila does not have a fund cite for your local transportation; therefore, be prepared to pay approximately $\$ 100$ (P2683.50) each for your roundtrip air fare (Manila-Tacloban-Manila) and claim reimbursement for same on your travel voucher.

Director Leonardo A. Nunez of the Bureau of Maintenance in the DPWH appears to be taking the lead on the GOP side and will accompany the team to Ormoc. Mr. Fortunato Dejoras (National Disaster Coordinating Council) will also accompany the team.

\section{John C. Starnes Office of Capital Projects}




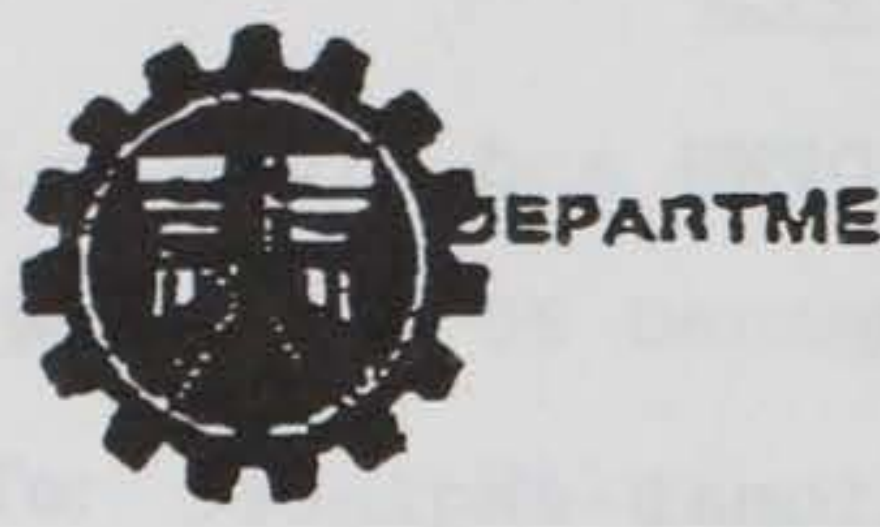

AEPUBUO OF THE PHUPPIAES

RECEIVEO

OFFICE OF THE 8ECAETARY

MANILA

llov at I is th :

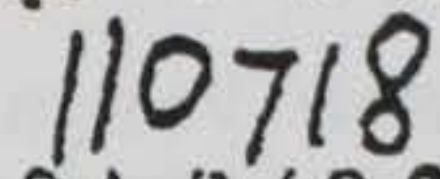

USA:O/C\&R

Novenber 19. 1982

MR. MALCOLY BUTLSR

Directer

Urited States Acancy for

Internations 1 Davalorment Man1la. PHIJ,ITRYNES

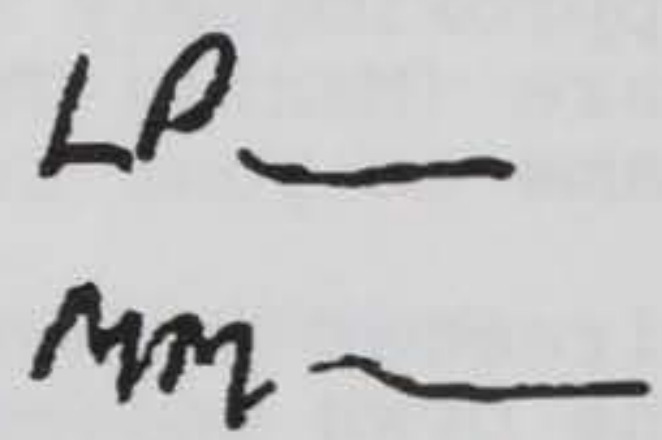

\begin{abstract}
ATTENTION: MR. LIEOY PURIEOY
Crief Englnane, OCP

REFERENCE: TYPHOON URTHO DAMACB AS8ESSTEIT

SURJBCT: REQUEST EOR TIR EHGAGMRBNT OF A SHORI IERY VISASTER EVALUATIOA TEAM EY USAID
\end{abstract}

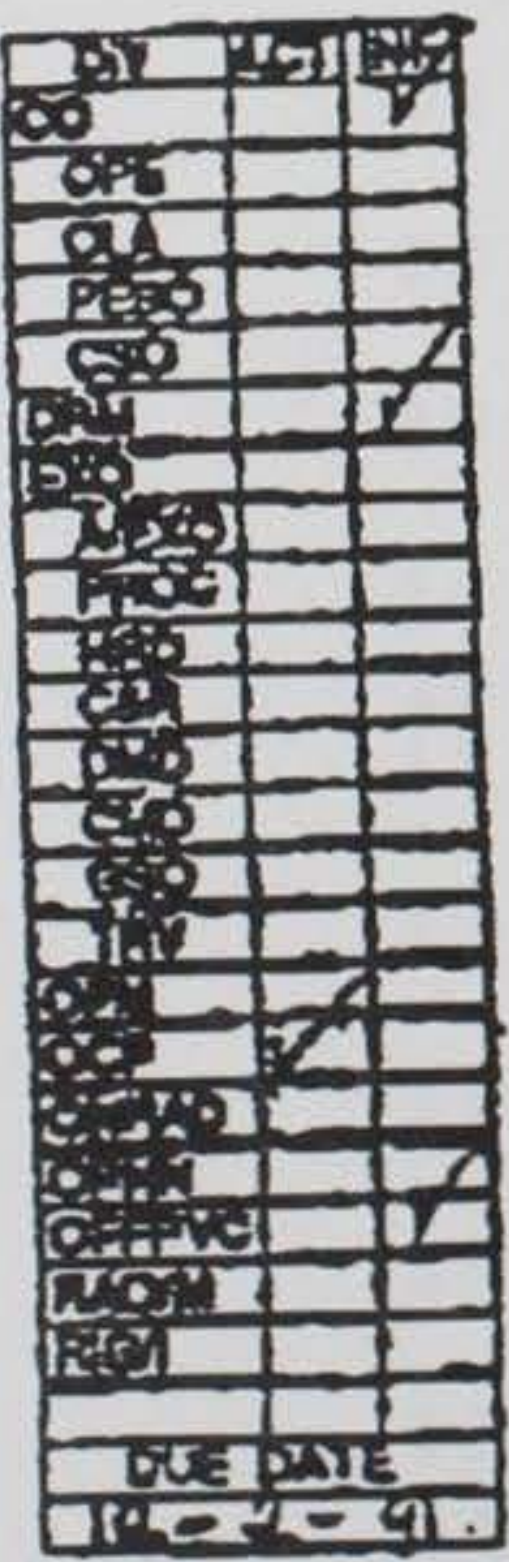

Deas Mr. Burter:

The Voparlinent of Publie Worko and HLetwaye is undertaking an investigation to determine the cause of the flooding which devartated Ormoe and tho gursounding communities lollowing Typhoon Uring in early Novamber 1991. We therefore seek tho asalstance of USAID in providing a team of disaster evaluation specialists from the US Army Corps of Engineers who will relp the Department in the ovaluatlon of the damege and in providine lnsight to the cause and pessible mitigation measures for the disseter.

Wo hope that USAID w1II consider this request favorably and sosim the epecialiat team as soon a poseiblo. DFWH is grateful to USAID for their contiaued aseistance and cooperation in our efforta to rehablitare disaseer arsas in the PhIllppines.

Sincerely,

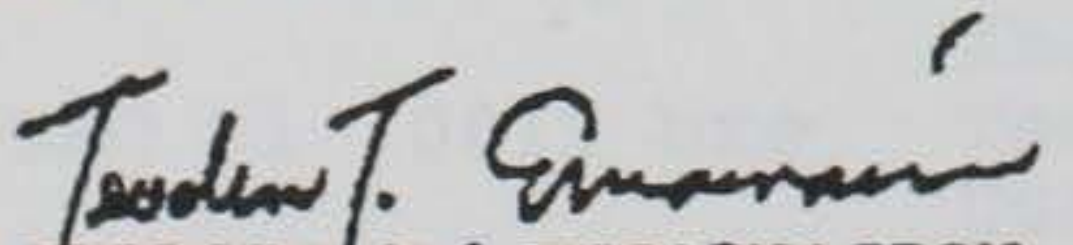
TTODORO T. IRICARAACION Undersecrstary

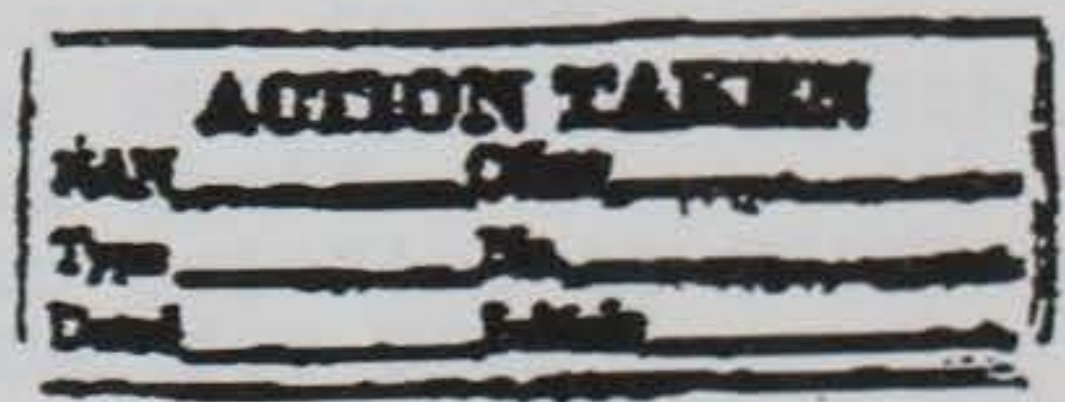




$$
\begin{array}{llll}
521534 & \text { VO:H }
\end{array}
$$

ERAN : OFFRUCUSAIDTMNILA

PHONE W. : 5215244

Nov. 281991 5:3APM Fa?

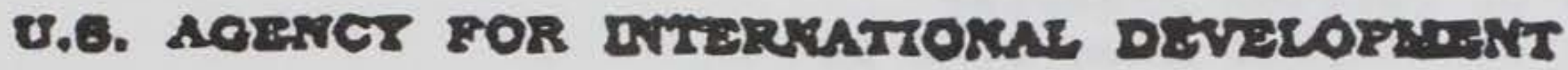

\author{
Ramen Merangry Conler

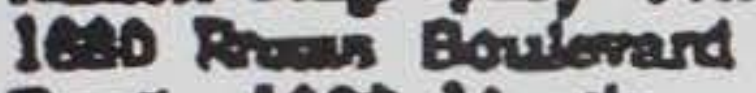 \\ i...in 1000. Murla \\ Puefipine
}

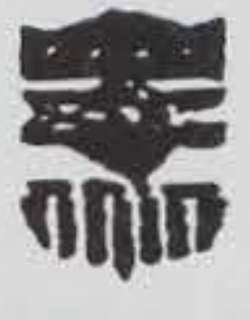

Thes No: 632-B2I- [2)

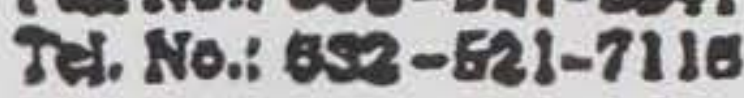

PAX 5O: RAY DIONNE
OFDA/AID/A

PNX MO: (202) 647-5269

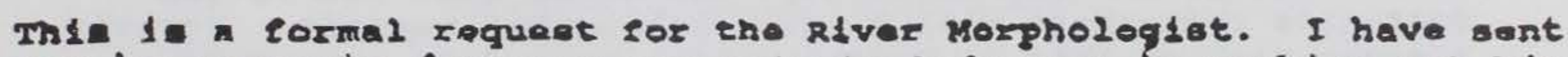
you by separate lax oow oomments to hedp you in working out nis contraet and anris. Thl 1s the lormal raguout. He have the sttached letter Eron the cop asking for this lislp. The seport w111 be a report to the COP and the UBG. The roport 20 r the oOP to yo to tho Department of Publlo Works and Hlghways and the USG Lu CeP.

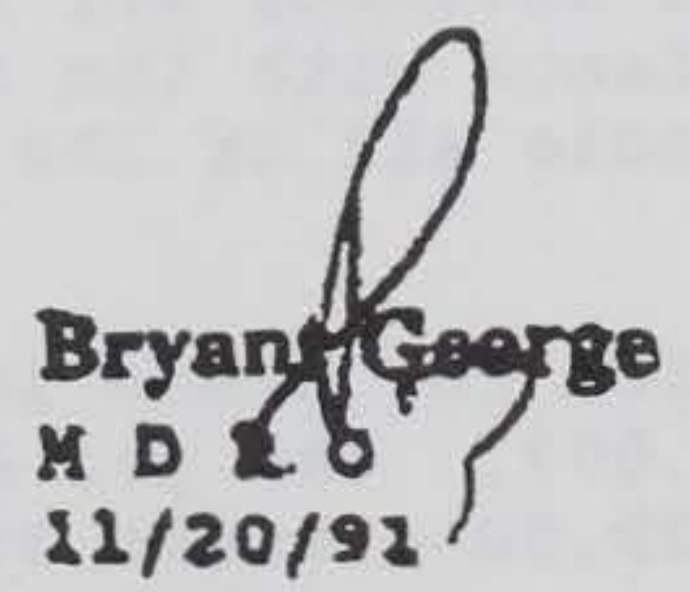

Attacheont: $a /$ w

Tp/bgdoe./21/20/91 


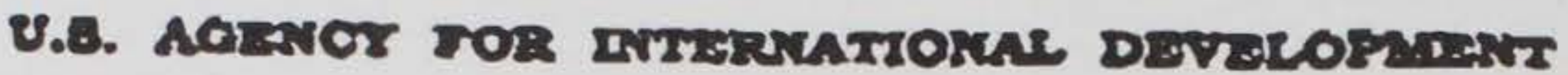

Pamog Mapey cantes 1680 Ram Boulvard crolila 1000. Marth Fralipatsos

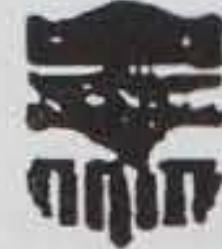

Pux Rio.: es2-521- 624i T내 16.: Q22-6)-7110

November 20, 1991

Mr. Ray Dlonne

Office of Foralgn Disater

Aesistance/As? Room 1052 NS

AID Wachdngton, D.C. 20523

Ray.

Thank you for forwarding the scopo of work propoeed by the Rlver Morphologiot. We have the followlng commentss

2. The base of operation rued to be raoloban or ormoc, very adeguate accompodations aro avallable. Mandla is far tois far away from th1s location to be of use as ase. Thla would be about an 4 hour a day convute.

2. Wo w1l attenpt to get hollcopter from private companies in the area or APP. Again, its too far from the suble $A B 8 E=8$, the teas we have doun enere now just not1fled me that they are taking a bus tror one locatlon to another. Then choppers ald not mater 1alize bocause of the newest $\mathrm{sto} \mathrm{rm}$ rayang, which makes It Impossible to fly. Basically, we cannot guarantee that there nill be hellcopter suppore the whole time but we can guarantee that ehere 122 be $80 \pi$ hellcopter support. Brwever, a great deal of this is going to have been done over radily roads and nore to secure bridges.

3. We can arzange for full meeting with and dobriefing by the Dept. of Public horks and glghways (DPWr) people of the country and meeting with the DAS's peopl who have nade thels evaluation of the area on November 15, 1991. In addition, we have excellent contacts with the shipping 1 in poople and transport people wo hanale all of the frelght to and from ormoc from cebu c1ty.

4. The per d1em for ormoc $18 \$ 45.00$ a day llodg1ag $18 \$ 23.00$ E meals are $\$ 22.00)$. The per diem for Tacloban $1 \mathrm{~s} \$ 57.00$ a day (lodgling $18 \$ 39.00$ meals are $\$ 18.00$ ).

5. We Will make a formal roquest for the service of this man/men as soon as we get a formal reguest from the Gop. Th1o is a highly sensltive lssue and we must have gop Fyency ready to hardie the flack that aurely 111 arise ferm ny report that the 086 cevelops no matter how 1t is

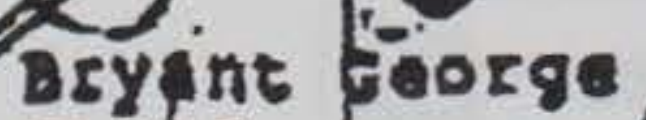
Cajoe OEElce fl pood por pace

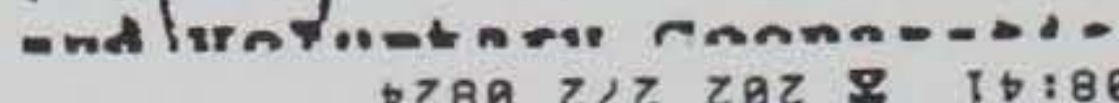
$\rightarrow 280 \quad 2 \angle 2 \quad 282 \& \quad 16: 80 \quad 16 / 22 / 1$ 
Appendix B: Rainfall Data NPOC 


\section{APPENDIX B}

PHILIPPINE NATIONAL OIL COMPANY (PNOC) RAINGAGE $1 \& 2$ DATA, LEYTE

DAILY RAINFALL DATA (in $\mathrm{mm} /$ day)

For the month of November 1991



LOCATION OF RAINGAUGE STATIONS:

1 - EDC Campsite Cabalonan
2 - TGE 11

RSAl jar:ilb 
Table 1

Monthly Rainfall (in mm) for VISCA Station North of Baybay Leyte




APPENDIX B

PHILIPPINE NATIONAL OIL COMPANY (PNOC) RAINGAGE 1 \& 2 DATA, LEYTE

DAILY RAINFALL DATA (in $\mathrm{mm} / \mathrm{day}$ )

For the manth of Navember 1991

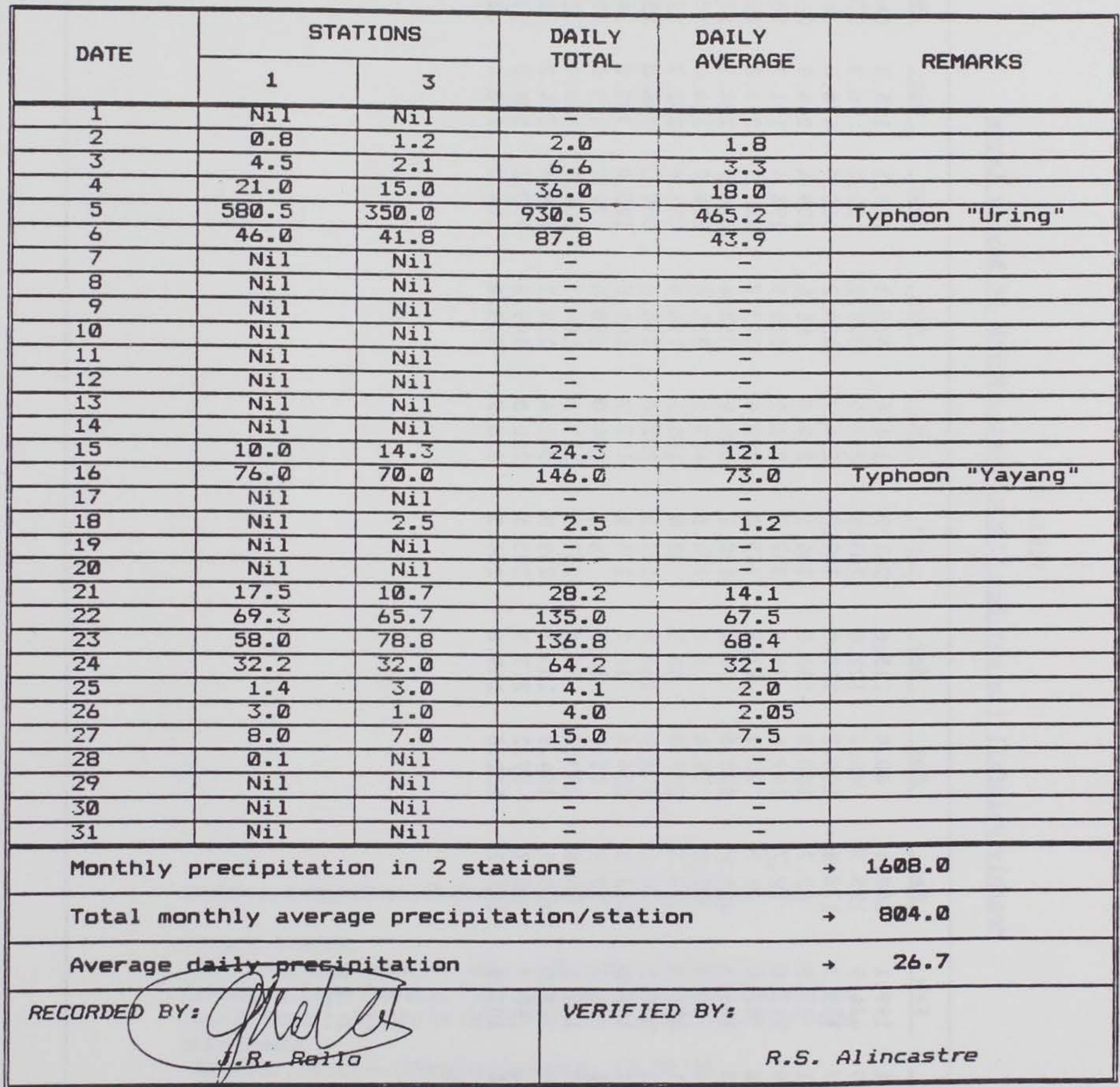

\section{LOCATION OF RAINGAUGE STATIONS:}

1 - EDC Campsite Cabalonan

2 - TGE 11 
Table 1

Monthly Rainfall (in mm) for VISCA Station North of Baybay Leyte

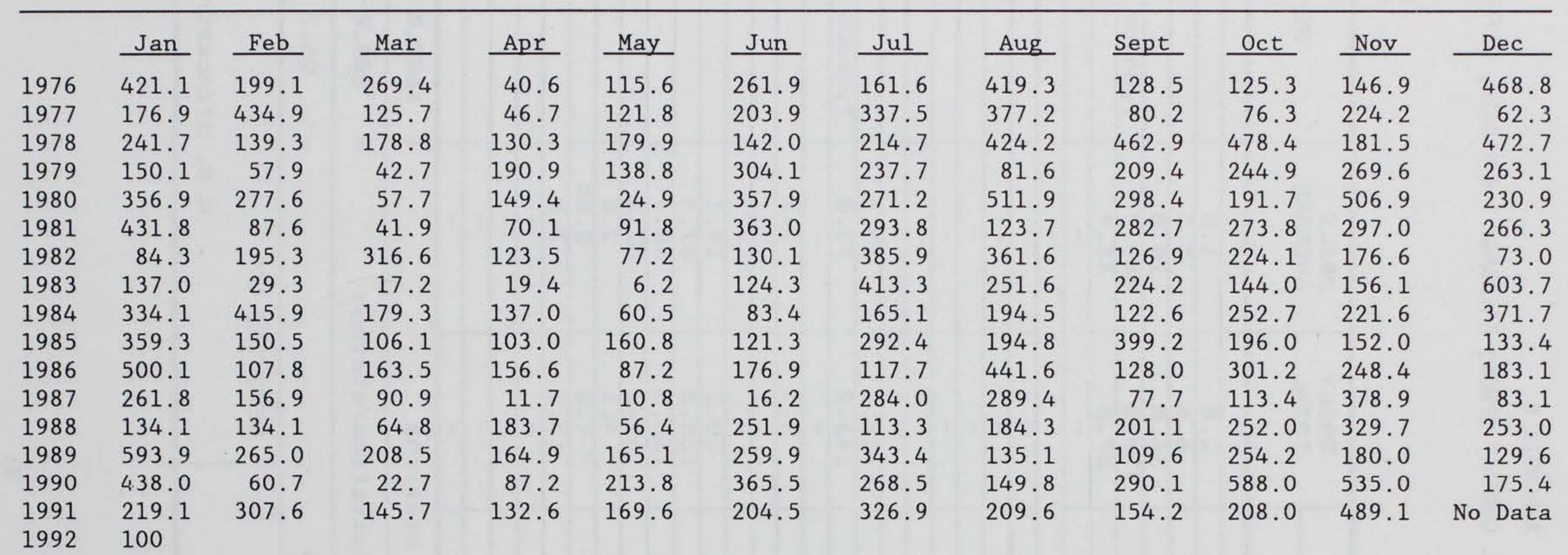

